\title{
The Hydrogeology of the Tully Valley, Onondaga County, New York-An Overview of Research, 1992-2012
}

\section{Introduction}

Onondaga Creek begins approximately 15 miles south of Syracuse, New York, and flows north through the Onondaga Indian Nation, then through Syracuse, and finally into Onondaga Lake in central New York. Tully Valley is in the upper part of the Onondaga Creek watershed between U.S. Route 20 and the Valley Heads end moraine near Tully, N.Y. (fig. 1). Tully Valley has a history of several unusual hydrogeologic phenomena that affected past land use and the water quality of Onondaga Creek; the phenomena are still present and continue to affect the area today (2014). These phenomena include mud volcanoes or mudboils, landslides, and land-surface subsidence; all are considered to be naturally occurring but may also have been influenced by human activity. The U.S. Geological Survey (USGS), in cooperation with the U.S. Environmental Protection Agency and the Onondaga Lake Partnership, began a study of the Tully Valley mudboils beginning in October 1991 in hopes of understanding (1) what drives mudboil activity in order to remediate mudboil influence on the water quality of Onondaga Creek, and (2) land-surface subsidence issues that have caused a road bridge to collapse, a major pipeline to be rerouted, and threatened nearby homes. Two years into this study, the 1993 Tully Valley landslide occurred just over 1 mile northwest of the mudboils. This earth slump-mud flow was the largest landslide in New York in more than 70 years (Fickies, 1993); this event provided additional insight into the geology and hydrology of the valley. As the study of the Tully Valley mudboils progressed, other unusual hydrogeologic phenomena were found within the Tully Valley and provided the opportunity to perform short-term, smallscale studies, some of which became graduate student thesesBurgmeier (1998), Curran (1999), Morales-Muniz (2000), Baldauf (2003), Epp (2005), Hackett, (2007), Tamulonis (2010), and Sinclair (2013). The unusual geology and hydrology of the Tully Valley, having been investigated for more than two decades, provides the basis for this report.

\section{Purpose of Report}

The purpose of this report is to summarize geologic, surface-water, groundwater, dendrochronologic (tree ring), and carbon-14 age dating studies completed within the Onondaga Creek watershed, primarily in the Tully Valley during 1992-2012. These studies were initiated to understand the hydrogeologic conditions that cause or contribute to mudboils, landslides, and other land-surface subsidence phenomena in the valley and how these features, in turn, affect the water quality of Onondaga Creek. Bedrock and glacial geology are summarized. Anthropogenic development in the valley is discussed because it might be related to some of these phenomena, and the general characteristics of mudboils, landslides, and land-surface subsidence are explained to provide context for the various studies that are discussed herein. Remedial activities designed and implemented to reduce the discharge of sediment and salty water from the mudboils to Onondaga Creek are reported, as are long-term monitoring trends. The potential for future remedial activities, aimed at providing long-term relief from the mudboils, is also discussed.

\section{Geologic History and Features of the Tully Valley}

The bedrock and glacial geology of the Tully Valley set the stage for human activities in the valley that may have compounded the natural phenomena of mudboils, landslides, and related land-surface subsidence. The halite (rock salt) resource deep within the bedrock sequence brought industrial development into the southern end of the Tully Valley in the form of drilling and solution mining of the halite for nearly 100 years. The layering of fine- and coarse-grained glacial sediments and the lack of a standing body of water in this Dry Finger Lake valley (Mullins and others, 1996) created semiconfined glacial aquifers with artesian pressure-heads several tens of feet above the valley floor that, in turn, cause mudboils or mud volcanoes to act and persist as naturally occurring pressure release valves within the Tully Valley. 


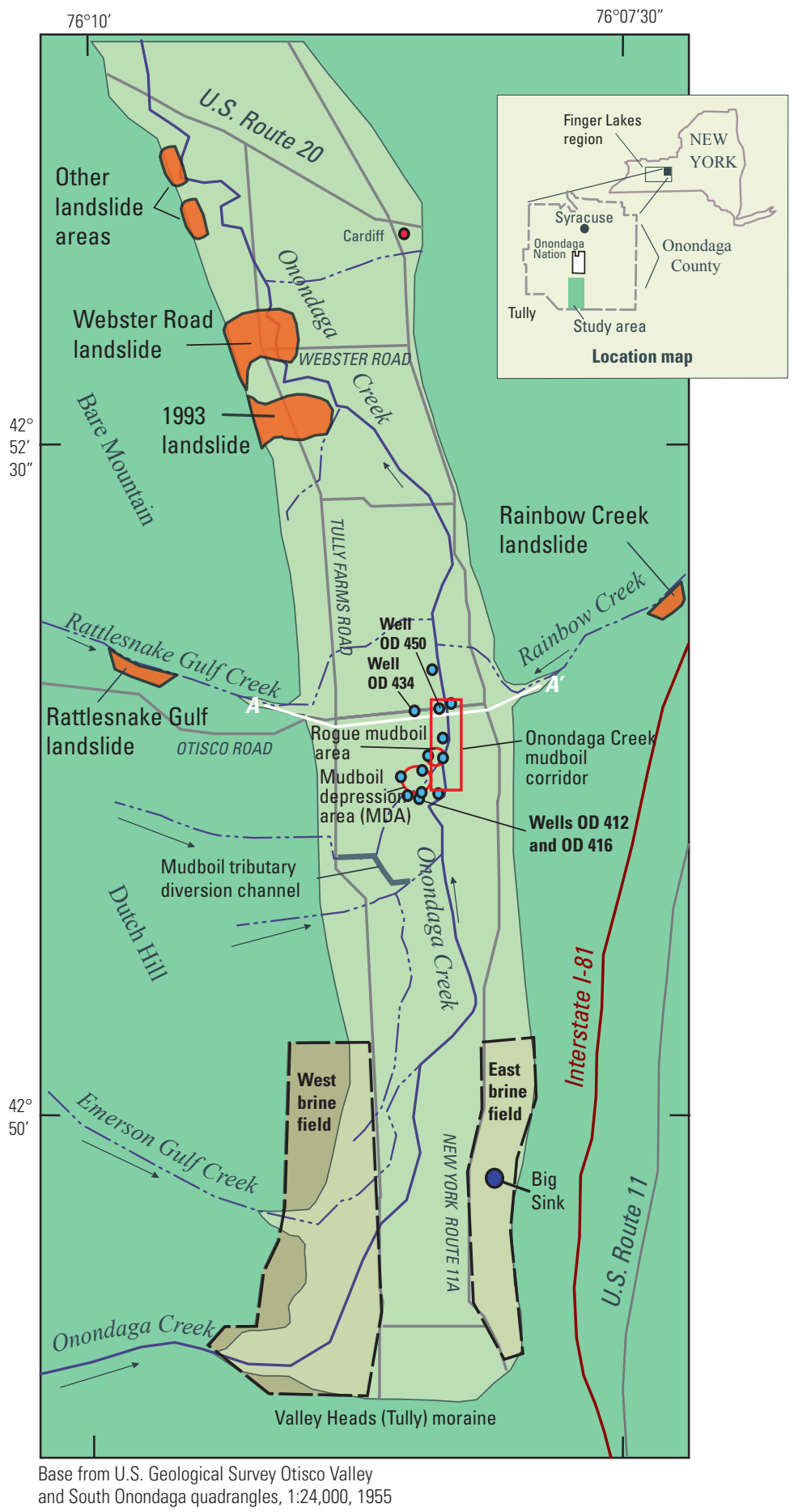

\section{EXPLANATION}

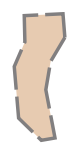

Tully Valley

brine field

Landslide area

Valley floor

Valley walls

Stream channel-arrow shows direction of flow

Line of geologic section $A-A^{\prime}$

sections shown in figures 2 and 3

- Depressurizing or monitoring well

- Cardif exploratory well, 1880's

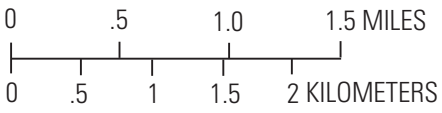

Figure 1. Physiographic features and well locations in the Tully Valley, Onondaga County, New York.

\section{Recent History of Mudboils-Factors Affecting Flow and Sediment Loading to Onondaga Creek}

[WY; water year. A water year starts on October 1 and ends September 30 and is designated by the calendar year in which the period ends.]

\section{1}

May-Slow collapse of Otisco Road bridge over Onondaga Creek begins. July-Mudboil appears upstream of Otisco Road bridge; bridge deck is removed soon thereafter. OctoberMudboil project by the USGS begins.

\section{WY 1992}

Mudboil Depression Area (MDA) discharged on average about 29.8 tons/day of sediment to Onondaga Creek. June-Diversion channel put into operation. Watershed area at MDA reduced from 1.02 square miles $\left(\mathrm{mi}^{2}\right)$ to $0.32 \mathrm{mi}^{2}$. Effect of diversion channel on sediment loading did not appear until later in 1992.

\section{WY 1993}

Water Year (WY) 1993-Mudboil area discharged on average about 9.8 tons/day of sediment to Onondaga Creek from October 1992 through July 1993. July, 1993-Bladder dam installed. In August-September 1993, the mudboil area discharged 0.4 tons/day. 


\section{Bedrock}

The bedrock in the Tully Valley spans the Upper Silurian through Middle Devonian sequence (fig. 2). The halite beds, which were solution-mined for saturated brine, are present within the Syracuse Salt of the Upper Silurian-Salina Group, at depths of 1,200 to 1,400 feet below land surface in the southern end of the Tully Valley. The bedrock valley is within Lower and Middle Devonian carbonates. Shale bedrock below the floor of the Tully Valley, and the steep valley walls, rising about 800 feet above the valley floor, are composed of Middle Devonian Hamilton Group shales (Kappel and others, 1996; Kappel and Miller, 2003, 2005).

\section{Glacial-Drift Deposits}

Over the past 2 million years, multiple periods of glaciation created the Finger Lakes region, which includes the Onondaga Valley. Ice advances widened and deepened former river valleys, and when the ice retreated from these valleys, a mixture of unconsolidated glacial sediments was deposited.

During the last glacial period (Wisconsinan) the Onondaga Valley was partly filled with till and stratified drift. The stratified drift included a fining-upward sequence of gravel, sand, silt, and clay deposited in proglacial lakes (fig. 3). During the final readvance of glacial ice in the Tully Valley section of the Onondaga Valley, ice overrode the lower stratified-drift deposits (below unit 7 in fig. 3) and advanced over the end moraine (Valley Heads moraine) at the southern end of the Tully Valley before retreating for the last time from the Tully Valley and the greater Finger Lakes region (Kappel and Miller, 2005). During this last retreat, a thick sequence (60-70 feet) of glaciallake silt and clay were deposited on the floor of the Tully Valley (units 6 through 3 in fig. 3), which caps approximately 350 feet of glacial drift. It is this upper silt and clay unit that confines artesian-pressured water within the glacial deposits that began, and continues to drive, mudboil activity.

\section{Mudboils}

A mudboil is created by artesian-pressured water that flows up through a confining layer of silt and clay and discharges both water and fine-grained sediment at the land surface. A typical mudboil vent (a nearly vertical pipe) carries very fine to fine sand, silt, and clay from depths of 60 feet or more to the land surface, where the fine sand settles out almost immediately and forms the volcano-like cone around the mudboil vent (fig. 4). The silt and clay entrained within this discharge initially remain in suspension; depending on the velocity of the receiving water,

\section{Tully Valley Hydrology}

A semiconfined aquifer controls the artesian head in the central Tully Valley that is currently [2014] about 20 to 30 feet above land surface. As is common in nature, hydrologic systems that are not in equilibrium make adjustments to reach that preferred condition - as is case at the Tully Valley mudboils.

By the early 1950s, the Onondaga Nation noted that the water quality of Onondaga Creek had changed; the water was continuously turbid, whereas periodic turbidity had occurred previously. Investigations by the New York State Health Department in the 1950s were the first to document the presence of mudboils ("mud pots" was their initial description).

When the brine mining operations ceased in the late 1980s and no brine was being piped to Syracuse, surface-water and groundwater conditions in the valley came to a new and likely elevated water-level condition, further affecting the hydrology of the Tully Valley and mudboil activity.

Until equilibrium conditions between the mudboil aquifer(s) and the surface-water system develop, mudboils and associated land-surface subsidence will continue, with possible changes in the water quality of Onondaga Creek resulting from fine-grained sediment discharges and changes in the chemical quality (salinity) of the water being discharged to the creek.

these fine-grained sediments either remain in suspension or settle out, with silt settling out first, while the clay remains in suspension to be carried farther downstream. The fine sand and silt can be deposited on the creek bed (as bed load) and can subsequently be transported farther downstream during high streamflows, eventually emptying into Onondaga Lake. The clay fraction usually remains in suspension and discharges to Onondaga Lake, where it settles to the lake bottom near the mouth of Onondaga Creek.

The removal of sediment at depth causes the overlying glacial sediments, primarily silt and clay, to slowly sag/subside to replace the sediment removed below the confining layer. The subsidence creates a series of circular ring fractures in the in situ soils around the discharging mudboil. As more sediment 


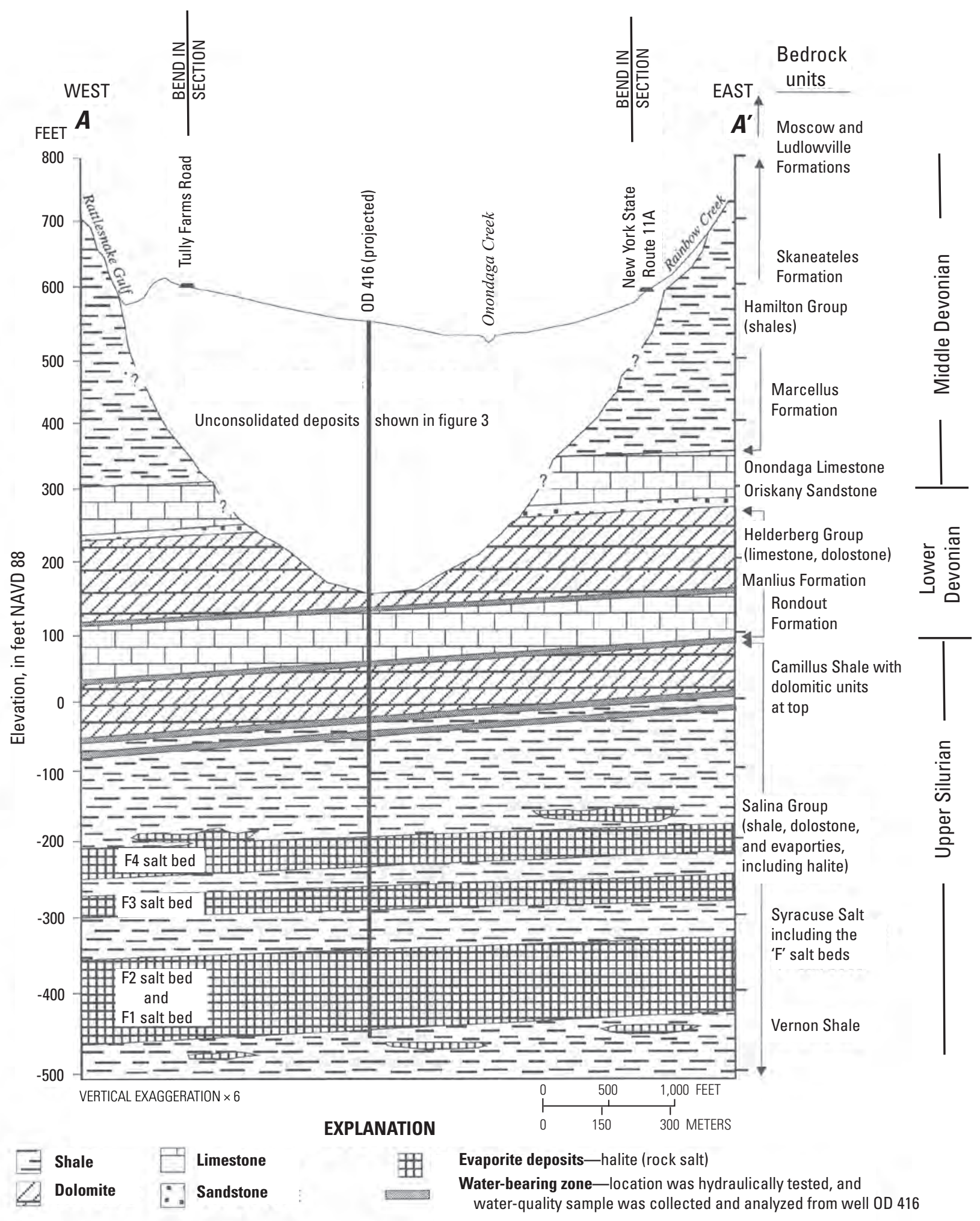

Figure 2. Geologic section $A-A^{\prime}$ showing major bedrock units below the Tully Valley mudboils, Onondaga County, New York. (Line of cross section shown in figure 1. Modified from Kappel and others (1996) and Getchell [1983]). 


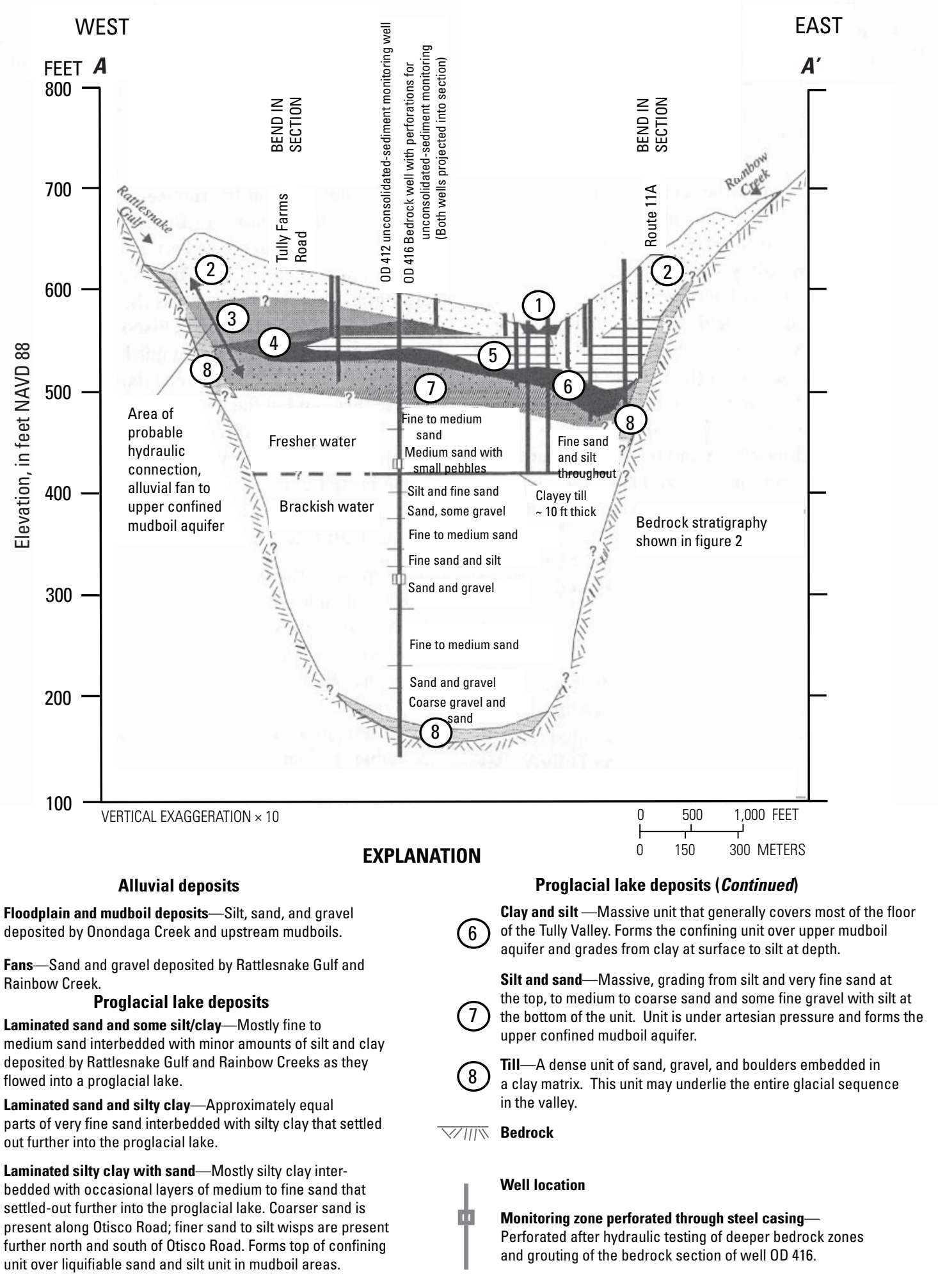

Figure 3. Geologic cross section $A-A$ 'showing glacial sediments near the Tully Valley mudboils, Onondaga County, New York. (Line of cross section shown in figure 1. Modified from Kappel and others [1996]). 

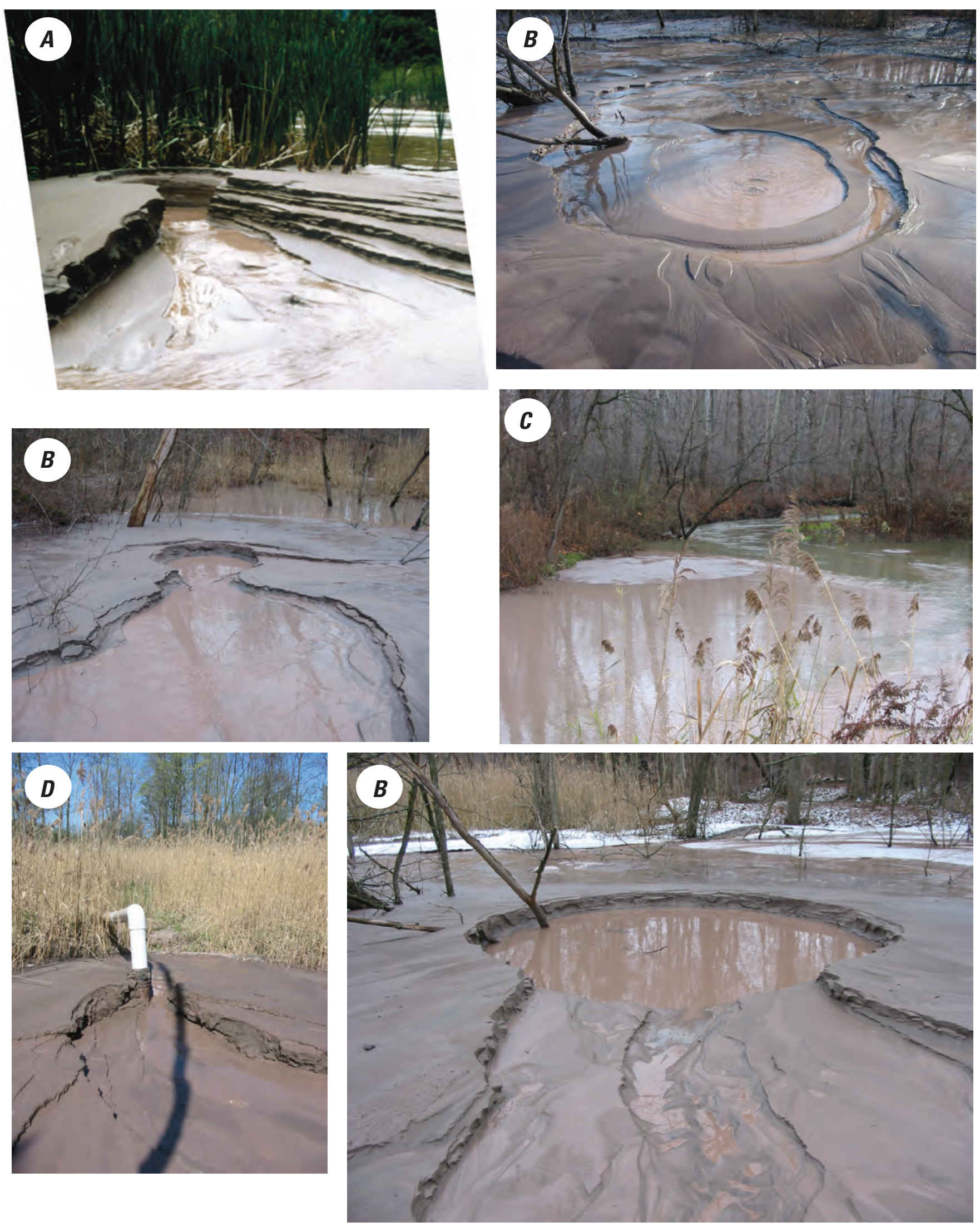

Figure 4. Mudboils in the Tully Valley, Onondaga County, New York, $A$, at the former main mudboil depression area; $B$, in the current [2014] Rogue mudboil area; $C$, in Onondaga Creek adjacent to Rogue mudboil area; and $D$, at the base of a former depressurizing well, before sinking into the ground, at the Rogue mudboil area. 
is removed at depth, additional ring fractures can develop outwardly, followed by additional land-surface subsidence. If, during subsidence, the vent is closed off or otherwise blocked, artesian pressure will increase until the water finds a new outlet, usually along one of the ring fractures.

A 1994 drilling project adjacent to the main mudboil area (Kappel and others, 1996, figs. 2 and 3) found that artesian pressure increases with depth and that the artesian pressure in the valley raises the groundwater head above land surfacethe flowing artesian water in 2013 had a head 20-30 feet above land surface near the mudboils. The flow of water and sediment, once initiated, will continue until the artesian pressure is reduced, whereby the artesian pressure driving mudboil discharge becomes insufficient for continuous discharge and becomes a seasonal discharge.

A groundwater-flow model of the Onondaga Valley glacialdrift aquifer by Yager and others (2007a and b) indicated that when mudboils and landslide spring discharges were removed from the model, the estimated artesian head was about 160 feet above land surface just after the last glacial lake drained. This excessive artesian pressure likely initiated mudboil activity following drainage of the last proglacial lake about 10,000 years ago. Appendix 1 includes two videos of land-surface subsidence in the Rogue mudboil area (http://pubs.usgs.gov/of/2014/1076/).

Fluctuations in artesian pressure in the glacial-drift aquifer are seasonal and dependent on recharge from (1) the end moraine at the southern end of the Tully Valley; (2) alluvial fans at the mouth of Rainbow Creek and Rattlesnake Gulf Creek, east and west, respectively, of the northern end of the mudboil corridor along Onondaga Creek; and (3) the bedrock valley walls to a small extent (Kappel and others, 1996). The confined aquifer(s) in the Tully Valley encompasses much of the glacial drift below the floor of the Tully Valley and the underlying bedrock. However, the glacial-drift aquifers are generally fine-grained materials (mostly fine to very fine sand with silt); therefore, flow rates from individual mudboils are relatively low (single digit to possibly a few tens of gallons per minute) and are dependent on the permeability of the sediments below the confining silt and clay layer and how well developed the vent pipe is between these sediments and the land surface. In these artesian-pressured, fine-grained systems, the rate of flow through the aquifer is generally low, although any change of artesian pressure resulting from recharge to the confined system can be transmitted through the aquifer fairly efficiently. Therefore, although the mudboil aquifer is not reactive to individual storms, mudboil discharge fluctuates in response to seasonal changes in precipitation, evapotranspiration, and recharge.

\section{Landslides}

Large landslide (mudslide) activity was not documented in the Tully Valley or its tributary valleys until the Tully Valley landslide occurred in April 1993 (fig. 5). As investigation of the 1993 landslide progressed (Wieczorek and others, 1998), it became apparent that this was not the first large-scale landsurface movement in the valley. Jäger and Wieczorek (1994) mapped a number of paleoslides (very old landslides) across

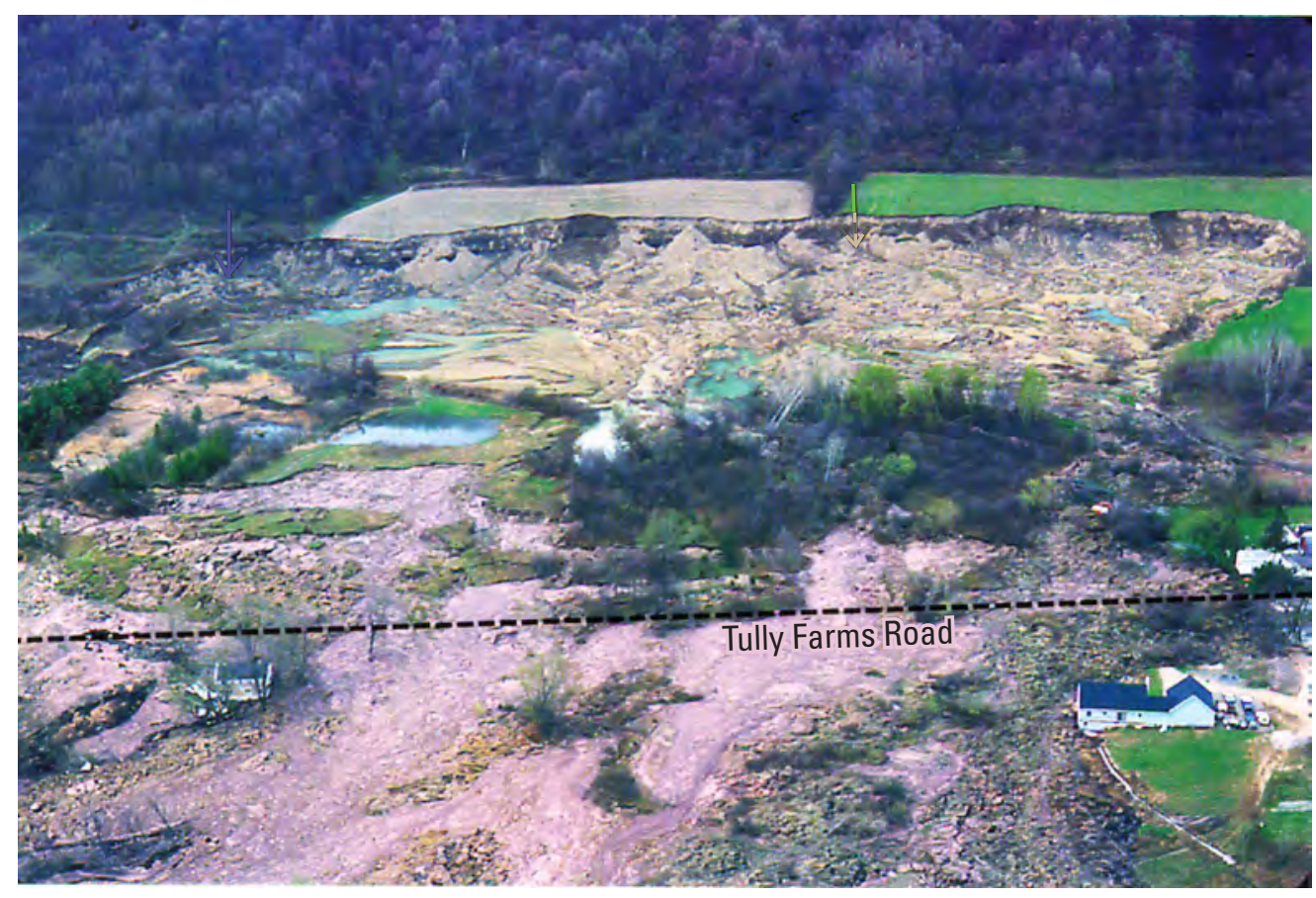

Figure 5. Area of the April 27, 1993, landslide, looking west toward the base of Bare Mountain, Tully Valley, Onondaga County, New York. 


\section{Mudboil History}

When the last glacial lake drained from the Tully Valley about 10,000 years ago, a large mudboil likely developed near the former Otisco Road bridge and created a large, nearly circular subsidence area at this location.

After the eruption of the first mudboil, the mudboil process became self-propagating. The mudboil activity continued over many thousands of years in a continual but likely sporadic manner in response to changing climate conditions, which, in turn, affected mudboil activity.

Development of mudboils appears to have progressed southward along Onondaga Creek (the mudboil corridor), with each area (old or new) alleviating some artesian pressure.

Mudboil activity is seasonal in nature and not reactive to individual storms, but it responds to seasonal changes in recharge, annual changes in the water budget for the valley, and longer-term changes in climate and land use.

southern Onondaga County, and a number of neighboring landslides were identified along the lower flank of Bare Mountain, north of the 1993 landslide (Pair and others, 2000). Additional landslides were identified in the Rattlesnake Gulf and Rainbow Creek tributary valleys (fig. 1) during 2004-5 (Tamulonis and others, 2009). The primary cause of these landslides is the proglacial lake clays that line the floor and lower slopes of these valleys. Some of these proglacial lake clays are beyond their liquid limits, which means they are not consolidated and can easily flow; are on steep slopes and prone to slip when saturated; and (or) are destabilized owing to erosion or construction. Most of the landslides that have been documented in upstate New York (Wieczorek and others, 1998) are associated with proglacial lake clays.

Age dating of a few of the Bare Mountain slides was accomplished through carbon-14 techniques (Pair and others, 2000); other slides were dated through dendrogeomorphologic means (Tamulonis and others, 2009 and Tamulonis and Kappel, 2009). Landslides in the Tully Valley can be either catastrophic or slow and range in age from current [2014] in the Rattlesnake Gulf Creek tributary valley to more than 11,000 years old in the Tully Valley (Pair and others, 2000). Although the occurrence of most of the large slides in the Tully Valley is infrequent, those in the Rattlesnake Gulf and Rainbow Creek tributary valleys have a prolonged history, as determined through the analysis of the earliest aerial photography in the region, from the late 1930 s to the present (2014), and by the recent dendrogeomorphic study (Tamulonis and Kappel, 2009).

\section{Anthropogenic Influences in the Tully Valley}

The influence of anthropogenic development on the hydrogeology of the Tully Valley (mudboils, landslides, and land-surface subsidence) is difficult to assess because few scientific data were collected before the early 1950s. Certain hydrogeologic phenomena within the Tully Valley might be related to human activities there - a timeline of brine and mudboil 'events' presented in appendix 1 of Kappel and others (1996, p. 58-63), and its supporting bibliography (p. 64-65) can be referenced for further information on each timeline event.

\section{Regional Settlement}

The Tully Valley was initially explored by Native Americans, followed by European settlement in the early 1800s according to a stage 1A cultural resource survey completed for the area in and around the mudboil corridor along Onondaga Creek (Wurst, 1994); the Tully Valley had a general store, hotel, school, and several different small industrial shops, including two water-driven mills, along Onondaga Creek by the mid-1800s. Clear cutting of trees from the valley floor and the surrounding hillsides (note hillsides in the background of figs. 6 and 7) changed the timing and amount of recharge from these hillsides to Onondaga Creek and might have contributed to mudboil activity and to landslide activity in the Rattlesnake Gulf area (Tamulonis and Kappel, 2009). Recovery to the current [2014] forested condition in the Tully Valley and elsewhere in central New York occurred during the 1920s and 1930s (New York State Department of Environmental Conservation, [2014]).

\section{Brine Mining}

Brine mining in the Tully Valley likely had a great effect on the hydrology of both the bedrock and glacial-drift aquifers in the Tully Valley. The soda ash manufacturing plant in Syracuse used the Solvay process to manufacture soda ash; the process required three main ingredients, ammonia, brine, and limestone (West, 1981). The Solvay process required a consistent and ample supply of 100 percent saturated brine; therefore, a protracted program to find the salt that supplied the naturally occurring brine springs near Onondaga Lake began in the early 1880s (Kappel, 2000). For nearly a decade the Solvay Process Company (SPC) explored for the halite resource in the greater Syracuse region and in 1889 was successful in finding halite in the southern end of the Tully Valley (fig. 7) at depths between 1,200 to 1,400 feet below land surface. Over the ensuing years, deep wells were drilled by the cable-tool method

\begin{tabular}{|c|c|c|c|c|c|}
\hline WY 1998 & WY 1999 & WY 2000 & WY 2001 & WY 2002 & WY 2003 \\
\hline $\begin{array}{l}\text { MDA discharged } \\
\text { on average about } \\
0.6 \text { tons/day } \\
\text { of sediment to } \\
\text { Onondaga Creek. }\end{array}$ & $\begin{array}{l}\text { MDA discharged about } \\
0.4 \text { ton/day of sediment to } \\
\text { Onondaga Creek. (October } \\
1998 \text { through June 1999-a } \\
\text { 9-month record). }\end{array}$ & $\begin{array}{l}\text { MDA discharged } \\
\text { on average about } \\
0.6 \text { ton/day of } \\
\text { sediment to } \\
\text { Onondaga Creek. }\end{array}$ & $\begin{array}{l}\text { MDA discharged } \\
\text { on average about } \\
0.5 \text { ton/day of } \\
\text { sediment to } \\
\text { Onondaga Creek. }\end{array}$ & $\begin{array}{l}\text { MDA discharged } \\
\text { on average about } \\
0.8 \text { ton/day of } \\
\text { sediment to } \\
\text { Onondaga Creek. }\end{array}$ & $\begin{array}{l}\text { MDA discharged } \\
\text { on average about } \\
1.4 \text { tons/day } \\
\text { of sediment to } \\
\text { Onondaga Creek. }\end{array}$ \\
\hline
\end{tabular}


$\mathrm{O}$ nce brine mining had begun in the southern end of the Tully Valley, the Solvay Process Company began their own farming operations to supply their workers in Syracuse with fresh produce, milk, and other food staples from the Tully Farms (fig. 6). The current [2014] north-south road on the west side of the Tully Valley received its name because of these farming operations-Tully Farms Road.
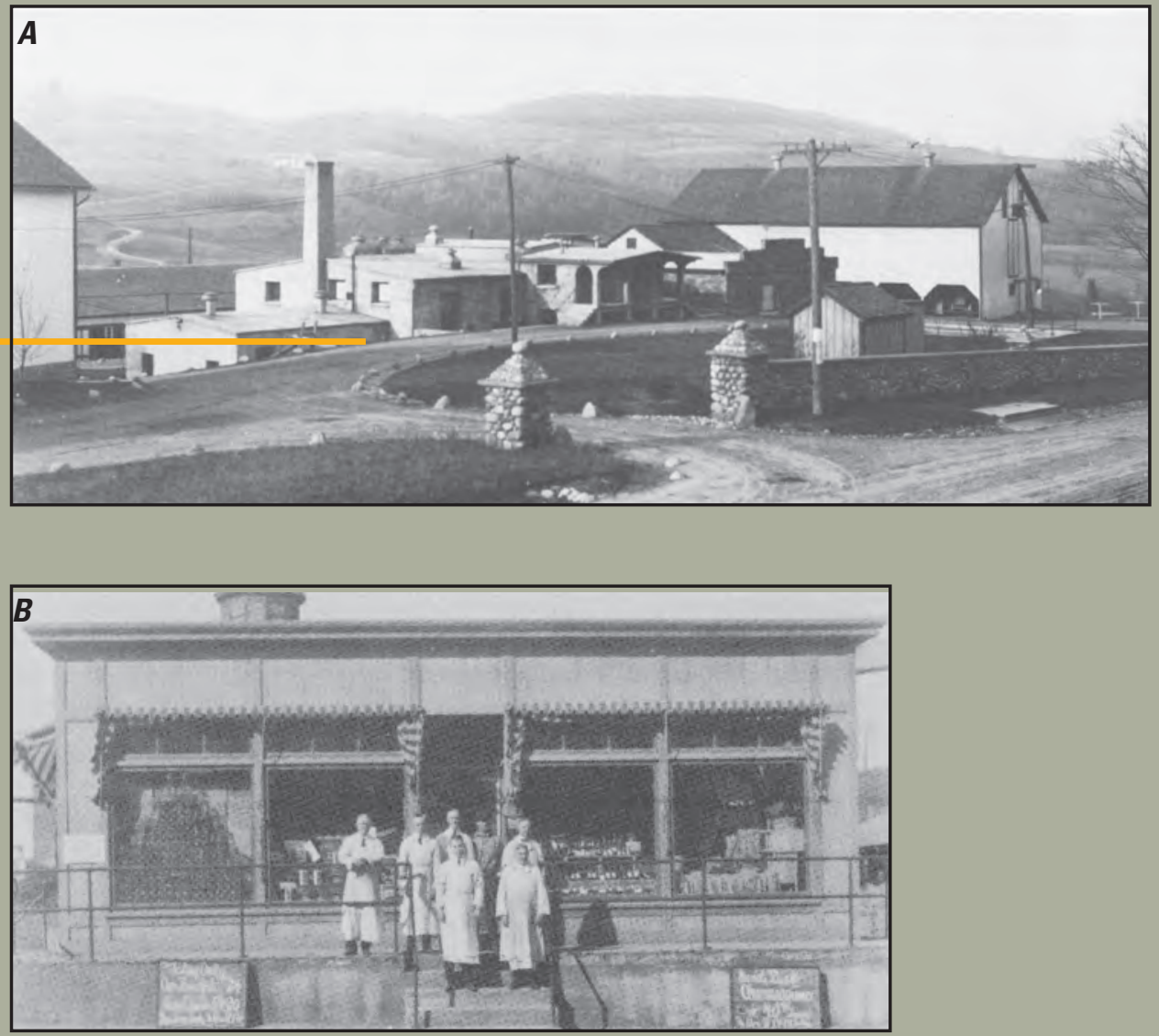

Figure 6. A, The creamery at Tully Farms with the west brine field in background, and $B$, the employee store at Solvay, New York. (From West, 1981.) to the halite layers, and water from the Tully Lakes, which lie just south of the Tully Moraine, was used to dissolve the halite and create saturated brine. The brine was gravity-fed through a pipeline system to the soda ash operations along the shore of Onondaga Lake in Syracuse, N.Y. (West, 1981).

In the years following the successful development of solution brine-mining operations in the Tully Valley, a composite thickness of nearly 150 feet of halite was continuously solution mined from the Syracuse Salt beds without leaving barrier walls or pillars for support of the overlying bedrock. As new solution-mining techniques provided increased halite recovery (Hackett and others, 2009), the mining of halite over a progressively larger area led to landsurface subsidence in the brine field areas, as was noted by the SPC in its field reports (The Solvay Process Company, 1950, 1960). The subsidence of bedrock from depths of 1,400 feet up to land surface altered the natural hydrology within and upgradient from each brine field. The flow of water within the bedrock changed from that of flow in discrete, nearly horizontal bedding-plane zones to that of uncontrolled fracture flow within the bedrock aquifer in the rubblized bedrock sequence. Surface water that previously flowed down the hillsides to Onondaga Creek was diverted into the new subsidence fractures in the bedrock and likely added recharge to the glacial-drift

\section{WY 2004}

MDA discharged on average about 1.2 tons/day of sediment to Onondaga Creek.

\section{WY 2005}

MDA discharged on average about 0.7 ton/day of sediment to Onondaga Creek.

During a fairly dry summer, extensive maintenance work was done at the MDA and Rogue areas - digging of a moat around the MDA, excavation of the Rogue impoundment, and redevelopment of five depressurizing wells. Well-redevelopment efforts resulted in little increase in flows, but sediment concentrations leaving the MDA and Rogue areas decreased in relation to the successful dredging activities. 


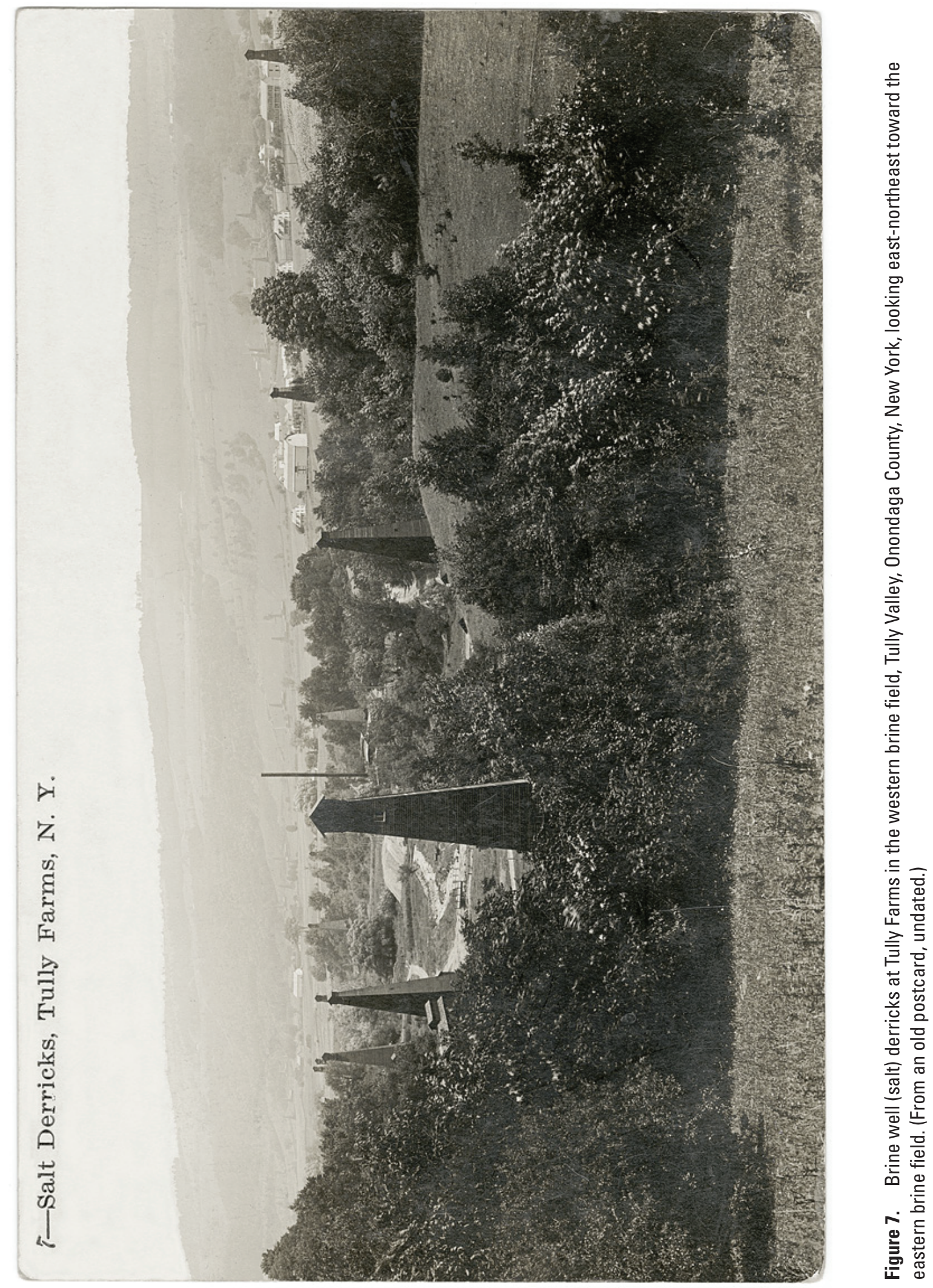


aquifer system within the valley. This new source of recharge likely increased the artesian pressure in the confined glacial aquifer, which, in turn, drove mudboil discharge from the upper (fresher) and deeper (brackish) parts of the aquifer near the mudboil area.

Land-surface subsidence in the brine fields, resulting from the removal of approximately 150 feet of halite, became so prevalent in the late 1950s that the eastern brine field was closed with all operations moved to the west brine field. During the following 25 years of brine-mining in the western brine field, nearly one billion gallons of brine was annually piped to the chemical manufacturing operations at Syracuse (Briggs and Sanford, 2000). All operations at Syracuse and in the Tully Valley ceased in the late 1980s because of the availability of other, more economical and natural soda ash resources elsewhere.

Closure of the solution-mining operations in the Tully Valley meant that a billion gallons of brine per year were no longer flowing to Syracuse; therefore, the hydrogeology of the Tully Valley changed once again. However, there was limited groundwater and surface-water information available for the nearly 100 years of brine mining to compare with hydrogeologic conditions following the cessation of brine mining.

The change in the hydrogeology of the Tully Valley after brine mining ended was initially considered by some to be a possible causative factor for the 1993 landslide. Homeowners who lived on the south side of the landslide indicated that their drinking-water supply, obtained from a series of springs at the base of Bare Mountain, had changed several years before the landslide (Yanosky and Kappel, 1998). The amount of water available had increased, but the quality of the water had become poor — with more hydrogen sulfide and increased salinity (Yanosky and Kappel, 1998). A dendrochronologic study of trees near these springs documented water-quality changes in the annual growth rings of trees within a wetland fed by these springs. This study also indicated that the brine mining several miles to the south (from the late 1880s to the 1980s) affected the quantity and quality of water discharging from these springs to the wetland. This information was developed through the analysis of tree rings from a number of trees within the wetland. Increases in the availability of water in the wetland were discerned from diminished annual tree-ring growth rates, and water-quality changes were discerned from chemical constituents present within the annual growth rings themselves (Yanosky and Kappel, 1998). These changes in the valley's hydrology and water quality do not appear to be the cause of the 1993 landslide because previous landslides occurred thousands of years earlier without the influence of brine mining or other anthropogenic effects.

\section{Brine Mining History}

Early in the brine mining operations (1890s), for every 100 gallons of freshwater injected into the halite, only 50 gallons of brine were produced.

When drilling in the bedrock, the early drillers (1890-1930) noted water cascading into the brine wells from the contact between the Oriskany Sandstone and the Manlius Limestone. This water was used to supplement the surface-water injections from the Tully Lakes.

Land-surface subsidence in the brine fields and associated fracturing of bedrock adjacent to the brine fields was reported by the brine mining company in the 1930s (Solvay Process Company, 1950, 1960).

The bedrock from land surface down to the halite $(1,200-1,400$ feet deep) is likely fractured as a result of the subsidence related to the extraction of 150 vertical feet of halite at depth in both brine field areas.

In the early 1960s, land-surface subsidence caused the closure of the eastern brine field.

By the mid-1900s, the mudboil aquifer was likely affected by the brine-mining operations in the southern end of the Tully Valley, according to the results of a dendrochronologic study of a wetland at the base of Bare Mountain, just south of the 1993 landslide area (Yanosky and Kappel, 1998).

\section{Documentation of Mudboil Activity}

The first historical account of a mud volcano in the Tully Valley was presented in the Syracuse Post Standard October 19, 1899. This short article reads:

"Few people are aware of the existence of a volcano in this town. It is a small one, to be sure, but very interesting. In the 20-rod gorge where the crossroad leads by the Tully Valley grist mill the hard highway bed has been rising foot after foot till the apex of a cone which has been booming has broken open and quicksand and water flow down the miniature mountain sides. It is an ever increasing cone obliterating wagon tracks as soon as crossed. The nearby bluff is slowly sinking. Probably the highway must sometime be changed on account of the sand and water volcano, unless it ceases its eruption."

This newspaper article accurately describes mudboil activity and resultant land-surface subsidence. The hard highway bed mentioned was Otisco Road where it crossed

\section{WY 2006}

MDA and Rogue area discharged on average about 0.6 ton/day of sediment to Onondaga Creek.

Owing to an above-normal amount of precipitation during 2006, a mudboil in the southwest corner of the MDA discharged large amounts of sediment and filled about 400 feet of the moat. These sediments were removed in summer 2006. Land surface subsidence was noted along the southwest rim of the MDA. Increased mudboil activity was also noted in the Rogue mudboil area with associated land-surface subsidence. The wells on either side of the Rogue area (OD 464 [streamside well] and OD 471 [fieldside well]) shifted, and soon thereafter sediment and turbid water discharged between well and surface casings, followed by the development of mudboils adjacent to the failing wells. 
Onondaga Creek at grade farther south (upstream) of its present location (fig. 1). The article also presages the collapse of the Otisco Road bridge 92 years later, in 1991.

\section{Early Mudboil Studies}

In 1950, a local resident noted constant turbidity in Onondaga Creek, 2 miles north of Otisco Road, and during the early 1950s the Onondaga Nation reported year-round turbidity in the creek (see Kappel and others, 1996, appendix 1). In 1951, the New York State Department of Health (NYSDOH) investigated Onondaga Creek and reported "suspended materials entering the creek south of Cardiff from springs and potholes" (Simpson, 1982). This report was followed by another study in 1955 in which NYSDOH noted "the presence of quicksand pits near Onondaga Creek tributary T-21 south of Otisco Road" (Snell, 1992). The tributary designated $\mathrm{T}-21$ drains the mudboil depression area (MDA) and what is currently [2014] the Rogue mudboil area.

In the mid-1960s, Roger Waller, a hydrologist with the USGS in Albany, N.Y., was compiling information on salt deposits across New York State and was in the Tully Valley gathering information on the Tully brine field. Mr. Waller noted, in crossing the Otisco Road bridge over Onondaga Creek, that the creek had a great deal of turbidity even though it had not rained previous to his visit. Speaking with local residents and investigating further, he found the main MDA located about 1,500 feet south of Otisco Road. Over the next 25 years, Mr. Waller continued to periodically visit the MDA and collect data on mudboil activity (fig. 8). Although not a formal USGS project, Mr. Waller did publish one small geologic note in 1977 describing the situation at the mudboils at that timepresumably at the MDA and along Otisco Road - and his understanding of the overall situation in the Tully Valley (see Waller, 1977).

The New York State Health Department was again called upon by the Onondaga Nation in 1981 to investigate the turbidity problem in Onondaga Creek and their effects on the biology of the Creek. A technical memorandum developed by Simpson (1982) described the macroinvertebrate fauna in Onondaga Creek upstream and downstream from the mudboils and in the Onondaga Nation farther downstream. The primary finding of this study was that although the creek was heavily affected by turbidity, the turbidity did not severely alter the macroinvertebrate faunal structure in the creek. This study was repeated in 1991 by Danehy (1993), who came to the conclusion that the invertebrate fauna were now affected by the turbidity in the creek. However, because the Danehy study was only a reconnaissance-level survey and because of a lack of funding, the study was not completed. In 1998, McKenna and others (1999) completed a macroinvertebrate and fish survey of Onondaga Creek from its headwaters to Route 20. This survey found good diversity for both fish and invertebrates, somewhat similar to the earlier findings of Simpson (1982). The different results among these macroinvertebrate surveys are likely linked to instream conditions of turbidity and specific conductance, which are linked to mudboil activity — which was not fully characterized in the earlier studies. The construction and operation of several remedial projects in and around the mudboil area, which began in the mid-1990s, reduced sediment discharge to Onondaga Creek and improved the water quality of the creek and its aquatic-insect and fish populations, as observed by McKenna and others (1999).

In the early 1980s, a Syracuse University graduate student developed a master's thesis on mudboil activity (Getchell, 1983) and attributed mudboil activity to enhanced dissolution of evaporite (halite or gypsum) deposits in bedrock, well below the MDA. Getchell (1983) related the brine mining in the brine fields to the south, at that time, to the dissolution of the halite below the MDA and the development of mudboils in the MDA, although he did not have any deep bedrock data to substantiate this concept. A report by Rubin and others (1991) ascribed the formation of the mudboils to the dissolution of salt beds in terms of a naturally occurring salt-dissolution front moving down dip from the north; this finding was based on the report of a bedrock void filled with moderately concentrated brine in an 1880s salt exploration well at Cardiff (fig. 1), northeast of the mudboil area (Kappel and others, 1996, appendix 1). This attribution was made without any data on underlying bedrock to confirm this concept. Haley and Aldrich of New York (1991), consultant to the Allied Corporation (formerly Solvay Process Company and currently [2014] the Honeywell Corporation), completed a report on mudboil occurrence, and although it did not attribute a cause of the mudboils, they did indicate the source of mudboil discharge was likely due to "structural features in the bedrock well below the land surface" (Haley and Aldrich of New York, 1991).

\section{U.S. Geological Survey Studies in the Tully Valley}

Beginning in fall 1991, the USGS became involved with the study of the mudboils and other hydrogeologic aspects of the surrounding Tully Valley. During 20 years, the USGS developed 22 reports related to the hydrogeology of the Tully Valley and the greater Onondaga Creek Valley (see Selected References). A comprehensive report on the Tully Valley mudboils and the nearby 1993 Tully Valley landslide was completed by Kappel and others (1996). This report summarizes data collected in and around the mudboil area and the 1993 landslide area at that time, including initial results of a series of mudboil remediation projects that were proposed and implemented through the Onondaga Lake Management Conference (OLMC) beginning in 1992. Five projects were proposed and implemented.

\section{WY 2007}

MDA and Rogue area discharged on average about 0.5 ton/day of sediment to Onondaga Creek.

Increased mudboil activity continued at the Rogue mudboil area (fig. 1) with associated land-surface subsidence. The upper depressurizing well (OD 471) disappeared into an adjacent mudboil, and there was a large mudboil at OD 464 that was close to the tributary stream and Onondaga Creek. Last summer two mudboils developed along the tributary channel. This area at OD 464 has also subsided by several feet. Dredging is to take place in summer 2008 at the MDA and Rogue areas. 


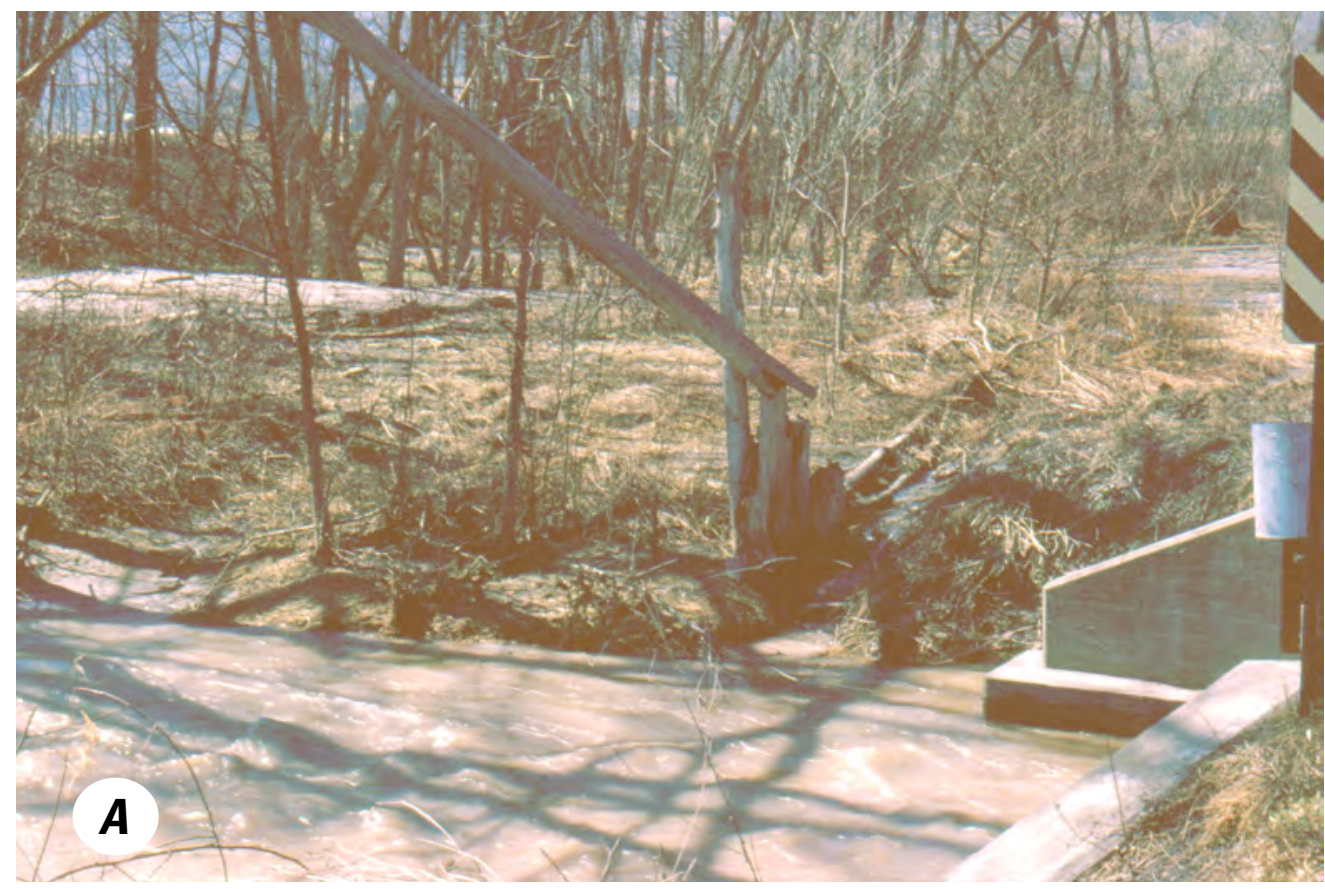

Photograph by Roger Waller of the U.S. Geological Survey

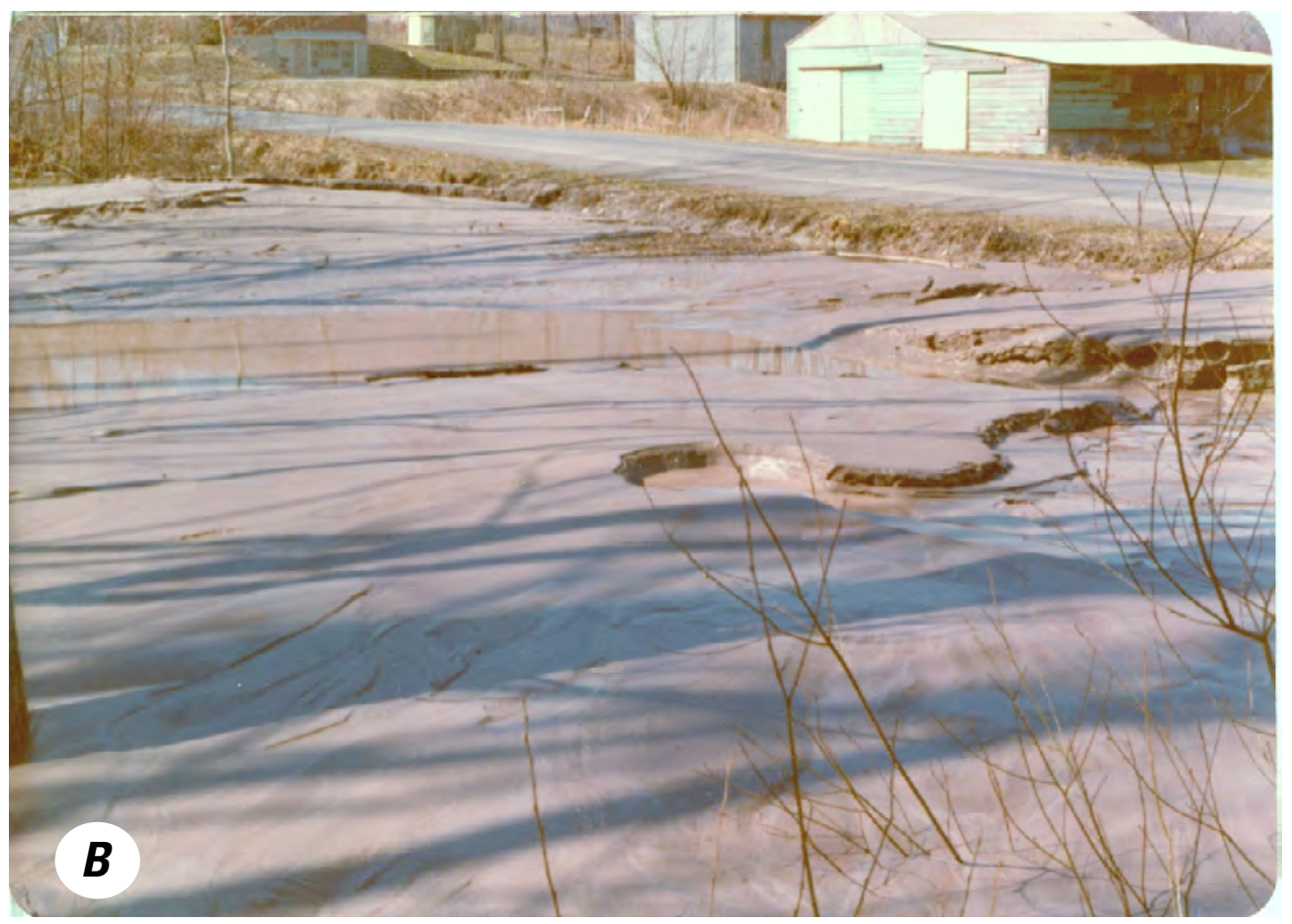

Photograph by Roger Waller of the U.S. Geological Survey

Figure 8. Mudboils adjacent to Otisco Road, Tully Valley, Onondaga County, New York, looking, $A$, west-southwest from the east side of the Otisco Road bridge toward the mudboils on the south side of Otisco Road, March, 1976, and B, northwest toward Otisco Road, March, 1977. 
1. Diversion of surface water from the watershed upstream of the mudboil depression area (MDA) (fig. 1). This diversion was implemented in 1992 to reduce flow into the MDA from the upstream watershed that carried additional sediment from the MDA to Onondaga Creek. The diversion was successful in reducing sediment loading to Onondaga Creek by about 50 percent - from an average of 30 short tons per day to about 15 tons per day (Kappel and others, 1996; Kappel and McPherson, 1998; Kappel, 2009).

2. The 1992-3 drilling program of deep exploratory wells in unconsolidated deposits (well number OD 412, fig. 1) and into the underlying bedrock (OD 416, fig. 1) down through the Syracuse Salt (containing the halite beds) to the top of the Vernon Shale (fig. 2). The deeper well, in bedrock, was cemented back upon completion of borehole tests, and two monitoring zones in the unconsolidated sediment part of the well were created and monitored. These wells were needed to understand (1) the stratigraphy of 416 feet of unconsolidated sediments and (2) the more than 600 feet of underlying bedrock to determine whether all of the halite units were present. It was found that all of the halite units were in place and unaffected by natural dissolution or dissolution caused by human activity. The two monitoring intervals in the unconsolidated deposits were measured over the following years for changes in artesian pressure and water-quality determinations (Kappel and others, 1996).

3. Construction of a temporary, followed by a permanent, water- and sediment-control structure at the outlet of the MDA in 1993-4. The temporary structure, a water-filled bladder, was constructed to test the concept of holding water over the mudboils to reduce sediment discharge from the MDA. The success of the temporary impoundment led to the construction of an earth-filled dam with outlet pipe and a downstream flume to measure flow and sediment concentrations and to develop sediment load calculations from the MDA to Onondaga Creek (Kappel and others, 1996; Kappel and McPherson, 1998; Kappel, 2009).

4. Drilling of a dozen depressurizing wells and associated monitoring wells in 1995-6 into the upper mudboil aquifer in the mudboil corridor and around the MDA. Test wells were drilled on either side of the former Otisco Road bridge in 1995-6 and were found to be marginally successful —one well averaged about 15 gallons per minute (gal/min) and the other averaged about $4 \mathrm{gal} / \mathrm{min}$ because of differences in glacial sediments at depth. These wells were monitored for flow and water quality for about 15 years. Additional wells were drilled in 1996 around the MDA and along the west side of the Onondaga Creek mudboil corridor. Discharges varied by well and also varied seasonally at each well. Depressurizing well discharges averaged between a few to more than $100 \mathrm{gal} / \mathrm{min}$, and water quality was measured intermittently over the same period (U.S. Geological Survey Annual Data Reports for New York, variously dated).

5. Long-term monitoring was conducted for:

a. Flow volumes at the MDA — nearly continuous monitoring, 1993-2010.

b. Hourly precipitation near Otisco Road-nearly continuous monitoring, 1993-2012.

c. Pressure heads or water levels at depressurizing and monitoring wells in and around the MDA and along Onondaga Creek - intermittent monitoring, 1996-2012.

d. Water quality from the MDA tributary stream and the depressurizing wells - seasonal or intermittent monitoring, 1993-2011.

These data are available from USGS annual data reports for New York (Hornlein and others, 1993-2005; U.S. Geological Survey, 2013a).

\section{Sources of U.S. Geological Survey Data}

Streamflow, water-quality and precipitation data collected in the Tully Valley can be found at the following locations:

- Streamflow-USGS Annual Data Reports, 1992-2012

- 1992 to 2002-Paper copy reports cited in Selected References

- 2003 to 2012 - Available from the Web at http://ny.water. usgs.gov/htmls/pub/data.html.

- Water-quality data and groundwater-level data-Appendix 2 (http://pubs.usgs.gov/of/2014/1076/).

- Precipitation-USGS Annual Data Reports, 1992-2012

- 1992 to 2002-Paper copy reports cited in Selected References.

- 2003 to 2006-Available from the web at http://ny.water. usgs.gov/htmls/pub/data.html.

- 2006 to 2012 - Not published, but available from New York Water Science Center office, Ithaca, N.Y.

- Well logs-Geologic information for selected wells. Appendix 3 (http://pubs.usgs.gov/of/2014/1076/).

\section{WY 2008}

MDA and Rogue area discharged on average about 0.6 ton/day of sediment to Onondaga Creek.

Increased mudboil activity continued at the Rogue mudboil area and well OD 464 continued to subside. Dredging of the southwest quadrant of the MDA and Rogue areas took place in summer 2008. In the brine fields south of the MDA, a 500-foot section of Emerson Gulf Creek (west brine field) was lined with clay to reduce surface-water infiltration to the local aquifer. In the east side brine field, the outlet of Big Sink was lowered by 15 feet to keep the sinkhole water level at its usual summertime low level to reduce surface-water infiltration to the local aquifer. 
The long-term monitoring program was designed to assess changes in flow, water quality, and mudboil activity in and around the MDA and within the Onondaga Creek mudboil corridor (fig. 1). Additional research activities related to the mudboils, landslides, and general hydrogeology of the Tully and Onondaga Valleys were developed to address the needs of the OLMC and its successor management agency, the Onondaga Lake Partnership (OLP). The varied nature of these studies enhanced knowledge and revealed the complexity of the groundwater-flow system in the Tully and Onondaga Valleys. These studies included dendrochronologic, geomorphologic, carbon-14 age dating of organic materials (wood, peat), surfacewater and groundwater modeling, water-quality monitoring, and land-surface movement and subsidence assessments (see Selected References for these reports).

\section{Results of U.S. Geological Survey Investigations in the Tully Valley, 1992-2012}

A summary of findings for USGS studies from 1992 through 2012 includes: (1) Discharge - surface water, as measured at the MDA outflow flume, and groundwater, as measured from depressurizing wells; (2) Water qualitysurface-water quality at the MDA flume, and groundwater quality from depressurizing wells; (3) Carbon-14 age datingcalibrated dates for several landslides along Tully Farms Road, northwest of the 1993 landslide, and from recovered organic material within the Onondaga Creek mudboil corridor; and (4) Land-surface subsidence assessment - at the mudboil area, primarily recent (2010-14) documented subsidence at the Rogue mudboil area and some historic subsidence as inferred from aerial photography from the late 1930s to present (2014). A concise history of mudboil activity, remediation efforts, and annual average daily sediment loading to Onondaga Creek for 1991 through 2008 is presented in Kappel (2009, p. 7), and a history for 1992-2012 is presented along the bottom of several pages throughout this report. Other USGS research in the Tully and Onondaga Valleys, although not summarized here, can be reviewed by using the Web links provided for all USGS reports listed in the Selected References at the end of this report.

\section{Discharge From the Mudboil Depression Area Tributary}

Flow measurements of water entering and leaving the MDA in the 1990s indicate that the discharge from the MDA mudboils varied seasonally and the discharge was dependent on annual precipitation trends. On average, mudboil discharge from within the MDA averaged about 325 gallons per minute ( gal $/ \mathrm{min}$ ) or about 0.75 cubic feet per second $\left(\mathrm{ft}^{3} / \mathrm{s}\right)$. This rate of discharge varied seasonally from more than $400 \mathrm{gal} / \mathrm{min}$ in the spring to about $200 \mathrm{gal} / \mathrm{min}$ in the fall $\left(0.9\right.$ to $\left.0.45 \mathrm{ft}^{3} / \mathrm{s}\right)$.
During very wet years, as much as $450 \mathrm{gal} / \mathrm{min}\left(1.0 \mathrm{ft}^{3} / \mathrm{s}\right)$ could be discharged from MDA mudboils; during dry years, as little as $50 \mathrm{gal} / \mathrm{min}\left(0.10 \mathrm{ft}^{3} / \mathrm{s}\right)$.

Overall discharge from the MDA (mudboil discharge within the MDA plus the small, 0.3-square-mile watershed upstream of the MDA) was summarized for water years 1993 through 2011 (U.S. Geological Survey, 2013a, station 04237946). The highest daily flow was $13.0 \mathrm{ft}^{3} / \mathrm{s}$ on March 24, 1994, and the lowest daily flow was $0.03 \mathrm{ft}^{3} / \mathrm{s}$ on September 27 , 1994. The 7-day minimum flow was $0.07 \mathrm{ft}^{3} / \mathrm{s}$. For the entire period of record (19 years), flows exceeded $1.5 \mathrm{ft}^{3} / \mathrm{s}$ only 10 percent of the time, exceeded $0.74 \mathrm{ft}^{3} / \mathrm{s} 50$ percent of the time, and exceeded $0.35 \mathrm{ft}^{3} / \mathrm{s} 90$ percent of the time.

For one well along Otisco Road (OD 434), a dedicated transducer was installed to monitor long-term changes in the artesian pressure of the mudboil aquifer at a depth of about 80 feet. The transducer functioned from 1994 through 1999, and another transducer was installed and functioned for an additional 2 years, 2008-9. The hydrograph of artesian pressure (fig. 9) indicates that the artesian head varied between 12 and 24 feet above land surface at this location and that the head varied seasonally.

\section{Discharge From Depressurizing Wells}

For the depressurizing wells, each 6-inch-diameter well discharged artesian-pressured water, and each had its own discharge rate that varied seasonally, depending on precipitation and recharge conditions. Discharge rates for most wells ranged, on average, from a few gallons per minute (gal $/ \mathrm{min})$ to tens of gallons per minute. Although most wells were completed with a 10 -foot well screen in the most permeable depth interval penetrated by each borehole, the amount of water that discharged from a depressurizing well was dependent on the permeability of the sediment at that location - the sediment stratigraphy (layering) varies across the mudboil area. In some cases, the well was screened in a very fine to fine, silty sand and discharged clear water at rates of 2 to less than $10 \mathrm{gal} / \mathrm{min}$. In some places where the well was screened in medium, silty sand, the discharge ranged from 10 to $30 \mathrm{gal} / \mathrm{min}$. Discharge varied seasonally, ranging between 30 to 50 percent greater than and 30 to 50 percent less than the average flow rate. Two wells were completed in medium gravel and did not have well screenswater flowed from the gravel into the open end of the well casing and discharged from 50 to more than $100 \mathrm{gal} / \mathrm{min}$. These open-ended gravel wells developed their own unique problems due to their high rate of discharge and are discussed in the Rogue Area Development-Likely Causes section in this report.

An aspect common to all the depressurizing wells is that, over time, the average discharge rate at the wells declined (fig. 10), and in some cases the discharge eventually stopped.

\section{WY 2009}

MDA and Rogue area discharged on average about 2.4 tons/day of sediment to Onondaga Creek.

Rogue mudboil area continued to be very active and well OD 464 continued to subside. The sediment sampling site was moved from the MDA tributary stream to just below the Rogue area because of the Rogue subsidence. The dike was rebuilt at the subsiding well (OD 464), and a pipe carried the well flow back into the Rogue area. In the brine fields, Emerson Gulf Creek (west brine field) had some erosion problems that were fixed by the County Soil-Water Conservation District, but the pond below the falls did not hold water-the beaver are gone. In the east side of the brine field, the outlet of Big Sink dried up, but flow returned after leaf-off. 


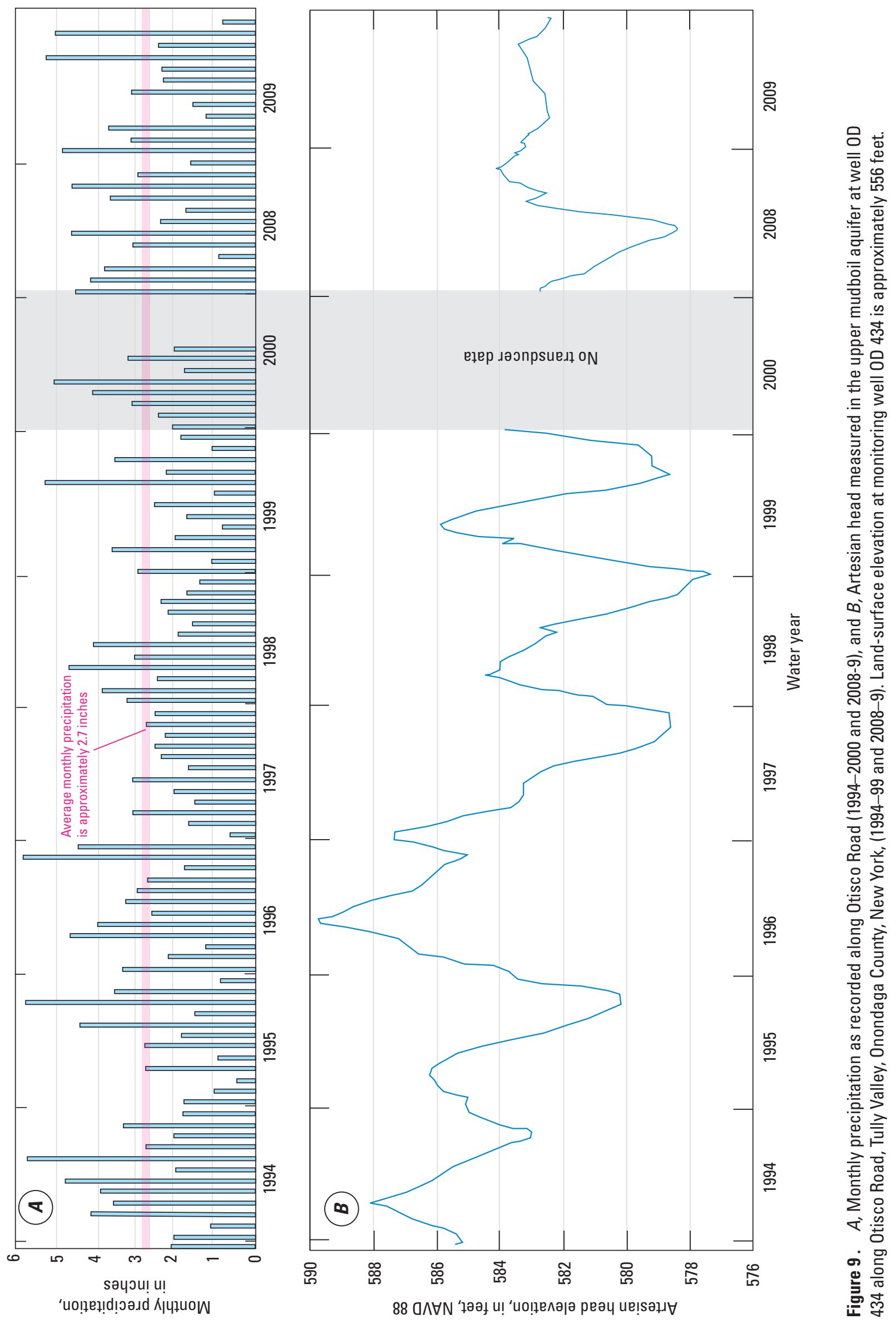


This change was likely due to the artesian-pressured flow of water that brought finer-grained sediment toward each well screen - in time, the aquifer outside the well screen would begin to clog with the finer-grained sediment, reducing the discharge from the surrounding aquifer to each well. An attempt was made to redevelop several of the wells by using high-pressure water injection and well surging to remove the finer-grained sediments outside the well screens to restore the original flow rate. In the five cases where redevelopment was implemented, two wells discharged less after development, two remained about the same, and one well discharged slightly more than its original discharge rate.

\section{Water Quality from the Mudboil Depression Area}

The quality of water leaving the MDA was defined by its chemical water quality and sediment quantity. MDA water chemistry was measured on approximately a quarterly basis for about 11 years, and the effects of dilution from the small upstream watershed did affect the chemical quality of water on a seasonal basis (U.S. Geological Survey, 2013b). However, over the long term, there was a trend toward higher specific conductance, as seen in the depressurizing wells (fig. 10), and an increase in some ions (U.S. Geological Survey 2013a and b), indicative of changes in the quantity and quality of water flowing from the upper, fresher-water aquifer and the lower, brackish-water aquifer. This finding is consistent with the early (1960-70) observations of Roger Waller (USGS, New York Water Science Center), who noted a change from just fresh water discharging from mudboils early in his investigations to salty water discharging from some mudboils by the 1980s.

Suspended-sediment quantity from the MDA mudboils, as measured by sediment concentration and calculated sediment loading to Onondaga Creek, varied seasonally and on an individual storm-related basis. The greater the amount of water flowing through the MDA, the higher the sediment concentrations and loads leaving the MDA as additional surface-water flow would entrain mudboil sediments. Flow from the mudboils, flow from the small upstream watershed, and precipitation falling directly on mudboil sediment within the MDA would affect sediment concentrations and loads. On
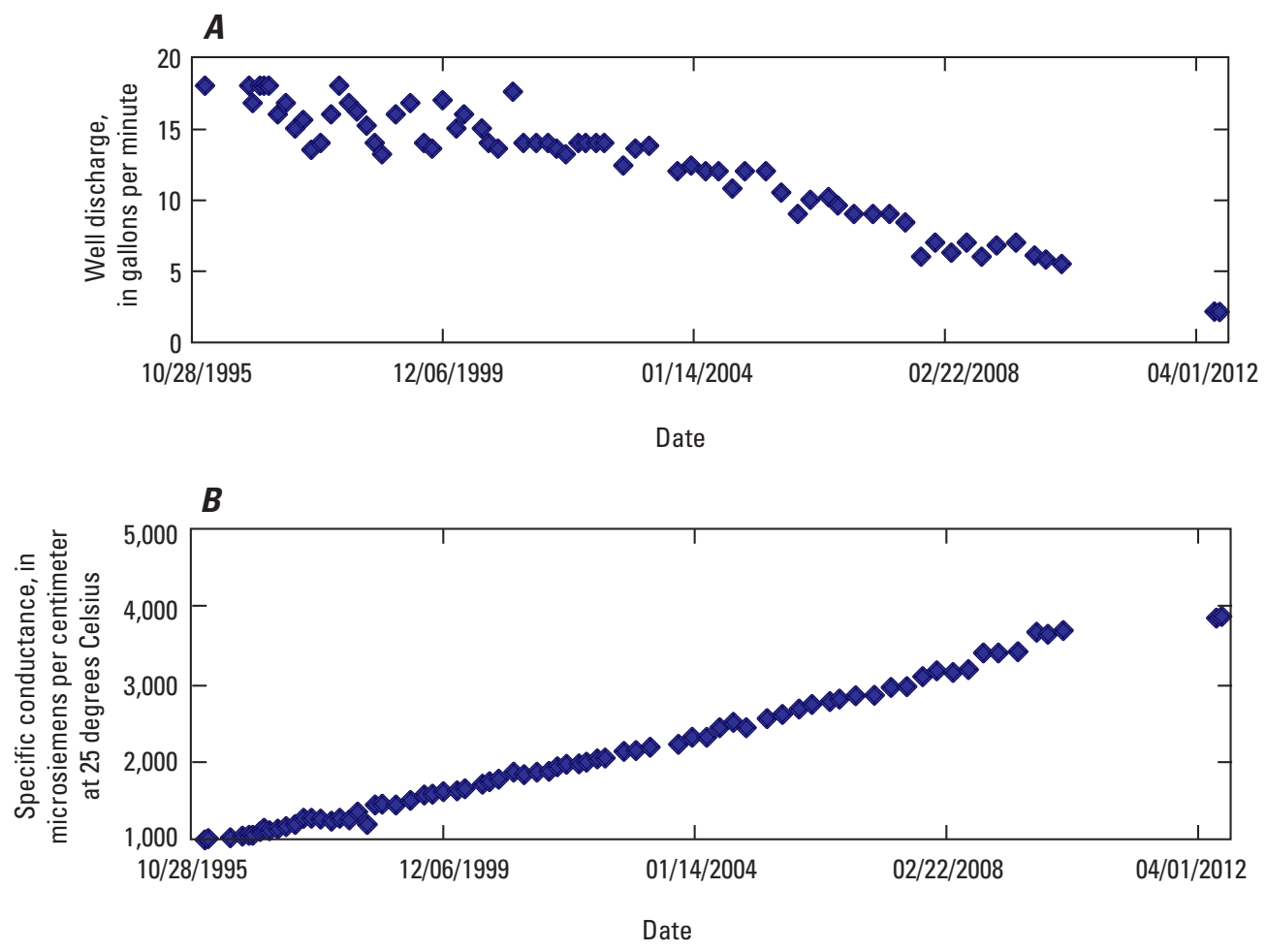

Figure 10. Trends in $A$, well discharge and $B$, specific conductance measured at depressurizing well OD 450, west side of Onondaga Creek at Otisco Road, Tully Valley, Onondaga County, New York, from December 1995 through August 2012.

\section{WY 2010}

MDA and Rogue area discharged on average about 0.6 ton/day before March 2010 and about 14.5 tons/day after March 2010.

Rogue area went rogue in early March-Well OD 464 disappeared into the ground, and a large mudboil developed in its place with no sediment retention-Onondaga Creek received a large amount of sediment, much like in early 1990s. Sediment sampling location was moved to Onondaga Creek at Otisco Road. Proposal to reroute creek was offered, but environmental concerns and uncertainty of success put construction on hold. Brine-field projects are generally unchanged. A Rattlesnake landslide again blocked the creek until water cut through landslide debris. 
average, the daily sediment discharge from the MDA, prior to any remedial efforts, averaged about 30 tons per day to Onondaga Creek, ranging from more than 100 tons per day during storms to less than 10 tons per day during dry summer periods (Kappel and others, 1996). The construction of the upper MDA watersheds mudboil tributary diversion channel (fig. 1) reduced the average daily sediment load by one-half, to about 15 short tons per day. Once the water-retention structure was built at the outlet of the MDA, the average daily load decreased to about 1 ton per day or less, and this rate remained relatively constant for about 12 years (Kappel, 2009). During this time, the mudboils continued to discharge sediment, but most of the coarser sediment (silt to very fine to fine sand) was retained behind the MDA structure and did not enter Onondaga Creek, eventually leading to the filling of the MDA with tons of mudboil sediment while the original land surface subsided below the accumulated sediment and the lateral expansion of the MDA (marked by ring fracture development) resulting from continued mudboil activity (Kappel and others, 1996; Kappel, 2009).

\section{Water Quality from the Depressurizing Wells}

Water quality from the depressurizing wells was measured on a rotating basis; chemical water quality (major cations and anions) was measured once every 2 to 3 years (U.S. Geological Survey, 2013b) and temperature, specific conductance, and salinity were measured quarterly. The wells exhibited a long-term change in water quality, as expressed by continual increases in specific conductance and salinity (fig. 10), as well as changes in ion concentrations over the 15 years (1996-2012) in which they were monitored. For wells that initially had specific conductance of several hundred microsiemens per centimeter at 25 degrees Celsius $\left(\mu \mathrm{S} / \mathrm{cm}\right.$ at $\left.25^{\circ} \mathrm{C}\right)$, specific conductance may have doubled over time, whereas for a well that initially had a specific conductance of several thousand $\mu \mathrm{S} / \mathrm{cm}$ at $25^{\circ} \mathrm{C}$, specific conductance may have increased by several thousand microsiemens per centimeter more. This finding follows the trend of increasing concentrations of chloride, specific conductance, and other constituents in water discharging from the MDA; that is, salinity in water discharged from the mudboil aquifers increased.

\section{Carbon-14 Age-Dating of Landslide and Mudboil Activity}

In the Tully Valley, organic samples (typically wood or peat-like material) were collected for carbon-14 age dating at the landslides near the base of Bare Mountain and the Onondaga
Creek mudboil corridor. The organic samples were age dated to provide a better historical understanding of the landslides and mudboils. Organic samples were also collected and analyzed in the city of Syracuse and in and near Onondaga Lake as part of water-quality remediation projects being developed in the greater Syracuse area. These samples were useful in age dating the glacial history of the Syracuse area (Kappel and Teece, 2007, table 1).

\section{Landslides}

The Webster Road landslide, just north of the 1993 landslide (fig. 1), was age dated at about 7,000 years before present, on the basis of organic material sampled at the interface between landslide-derived sediment and the former soil surface (Pair and others, 2000). An older landslide remnant below the 7,000 year event (several trees that appeared flattened and aligned in the Onondaga Creek streambed) was age dated at more than 11,000 years before present (Pair and others, 2000). Another landslide area farther to the north, in a 15-foot-thick peat deposit that was apparently overturned, was age dated at 4,700 to 8,100 years before present (Kappel and Teece, 2007).

\section{Onondaga Creek Mudboil Corridor}

Within the Onondaga Creek Mudboil Corridor a number of trees buried several hundreds to over a thousand years ago were found and age dated (fig. 11A-C). A tree downstream of the former Otisco Road bridge (11A) had an age of about 675 years before present. Within the mudboil corridor, a number of carbon-14 ages were determined in anticipation of the proposed alignment of a diversion channel for Onondaga Creek around the Rogue mudboil area in 2010. In shallow alluvial floodplain sediment (1-4 feet deep), the ages of woody material ranged from about 350 to 500 years. When an excavator was used to dig deeper test holes, two large-diameter trees, a walnut and a sycamore, were recovered from coarse gravel in two different test pits at depths of about 6.5 feet (fig. 11B). Wood from the sycamore tree was dated at about 1,350 years before present, and wood from the walnut tree was dated at about 950 years before present. In one of the test holes, the excavator dug to a depth of 12 feet, and as the operator probed deeper with the excavator bucket, he did not penetrate red clay, which typically is present close to land surface across the floor of the Tully Valley. In the southern end of the mudboil corridor, the base of a tree that grew on clay at the eastern edge of the alluvial fan was exposed in the channel of Onondaga Creek (fig. 11C) and was age dated at approximately 6,800 years before present.

\section{WY 2011}

MDA and Rogue area discharged on average about 26 tons/day of sediment to Onondaga Creek.

Rogue area continued to discharge sediment directly to the creek, and beginning in early June, massive subsidence occurred along the western edge of the area. During the next 6 months subsidence spread into the farm field. Sporadic mudboils appeared along the creek side of the Rogue, causing further stream and east bank subsidence; most of this was caught on time-lapse cameras. Stream-discharge gage at the MDA was moved to Onondaga Creek at Otisco Road in August. All sediment sampling was moved to Otisco Road. Brinefield projects were unchanged. Tropical Storm Lee caused Big Sink flow to resume for a short period, returning to a full-time discharge later in the fall. Rattlesnake Gulf continued to have small and large slumps, and the Rainbow Creek slide appeared to have come to equilibrium - water flows were mostly clear year-round, as opposed to the turbid to very turbid flows seen at Rattlesnake Gulf Creek. 


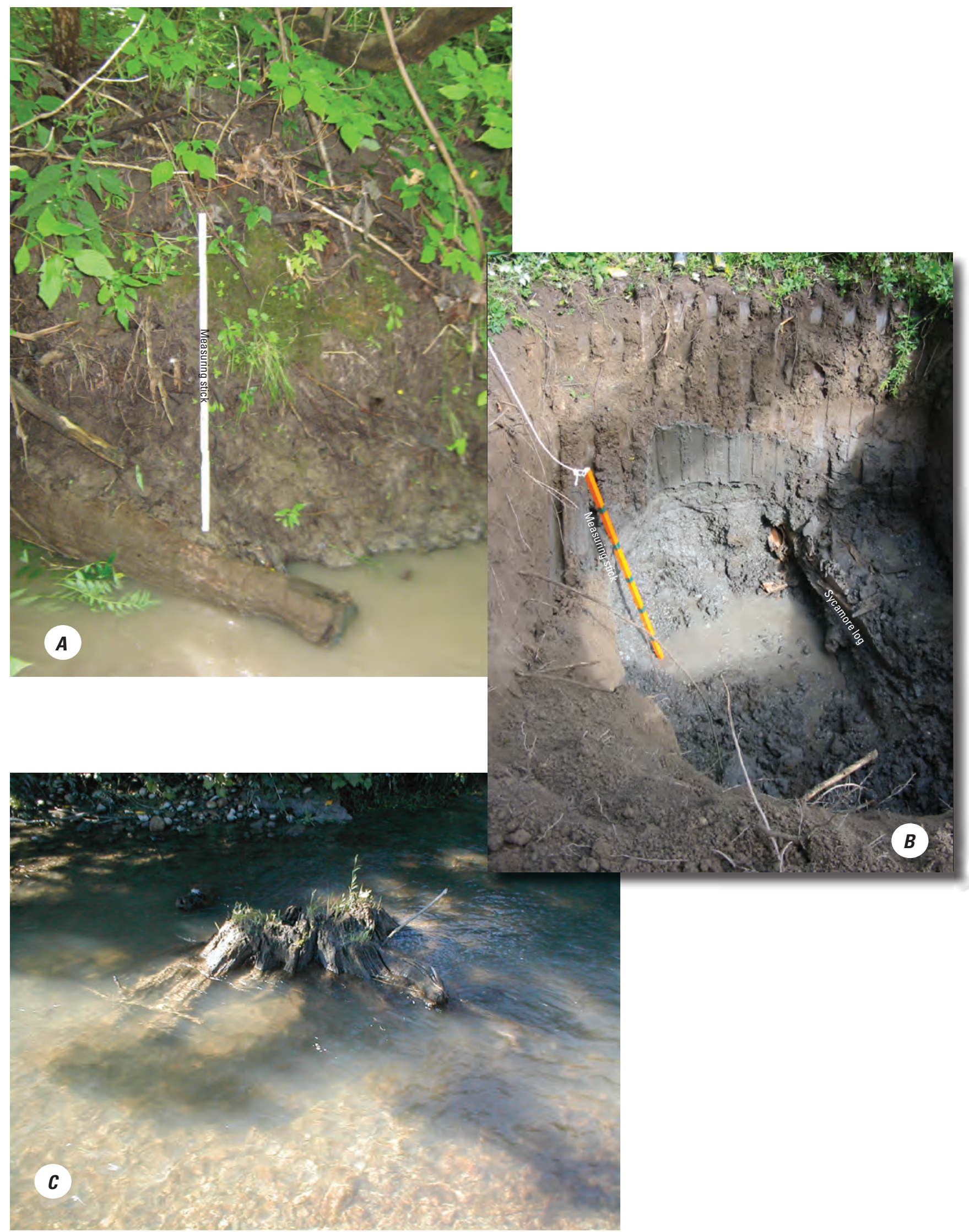

Figure 11. Wood samples found in the Onondaga Creek mudboil corridor, Tully Valley, Onondaga County, New York, $A$, log in streambank downstream from the former Otisco Road bridge in fine-grained alluvial sand and silt; $B$, log on right side of test pit east of the Rogue area, in grey sand and gravel below red-brown, fine-grained alluvial sediment, and $C$, tree stump in Onondaga Creek upstream of the Rogue area, in red lacustrine clay. Age of $A$ is approximately 675 years before present (BP), of $B$ is approximately 1,350 years $\mathrm{BP}$, and of $C$ is approximately 6,760 years $\mathrm{BP}$. 
These carbon-14 dates, along with the coarse gravel material present at depth in the corridor and not the surficial red clay that is found upstream and downstream from the mudboil corridor in Onondaga Creek, are indicative of longterm mudboil activity and land-surface subsidence in the corridor long before human activities could have affected the mudboil corridor.

\section{Mudboil Activity Within the Mudboil Corridor and the Rogue Mudboil Area}

The age dating analysis of woody (organic) material from within the mudboil corridor indicates a time span of more than 1,300 years of mudboil activity. The progression of mudboil movement in the corridor, however, is not well understood and, on the basis of field observations from the 1970s to 2012, appears random.

\section{Mudboil Corridor}

The Onondaga Creek mudboil corridor extends from north of Otisco Road to approximately 1,800 feet south of the former bridge that crossed Onondaga Creek (fig. 1). Aerial views of the mudboil corridor showing known and suspected mudboil activity from the late 1890 s to 2013 are presented in figure 12. The calendar-year dates were derived from anecdotal and written reports of mudboil activity, review of aerial photography, and field observations by the USGS. Other dates were assigned to areas of mudboil activity on the basis of information provided by organic material (carbon-14 ages in years before present) obtained at various locations and depths in the corridor. The appearance, intensity, and duration of mudboil activity within the corridor from 1899 to 2013 appears to be random with no consistent pattern.

\section{Rogue Mudboil Area}

The Rogue mudboil area got its name in 1997 after a depressurizing well (OD 464, known as the creekside well) was drilled along Onondaga Creek in fall 1996. This well was finished in medium gravel and flowed at more than $50 \mathrm{gal} / \mathrm{min}$. The discharging water was always slightly turbid, unlike all other depressurizing wells.

\section{7 to 2001}

Early in 1997, the creekside well was scheduled to be deepened to shut off the turbidity, but when the driller arrived, he found a small mudboil in the middle of the access road.
Rather than try to get to the well, another well was installed upgradient, near the edge of the farm field. This well (OD 471, known as the fieldside well) was finished in coarse gravel at a higher elevation than the creekside well and discharged more than $100 \mathrm{gal} / \mathrm{min}$ for several years.

\section{1 to 2010}

Over time, the two Rogue-area depressurizing wells continued to produce copious amounts of water, with some turbidity discharged from the creekside well. The Rogue mudboil in between these wells continued to grow slowly. Initially the Rogue mudboil was surrounded by sand bags to keep sediment out of the creek, but because the mudboil continued to grow in lateral extent, it was determined in 2001 that an earthen dike should be placed around the Rogue mudboil area with an outlet gate to retain sediment but allow the somewhat less turbid water to flow to the MDA tributary stream and then to Onondaga Creek. Over the ensuing years, the Rogue mudboil became larger, causing ring-fracture development and land-surface subsidence; the diked area filled with sediment that needed to be removed periodically. Sediment was removed from inside the Rogue mudboil dike in 2005 and 2008, and a minor repair was made to the creek side of the dike in 2006. During this time, subsidence around the Rogue area was expanding, mostly on the western (farm field) side of the area. The fieldside well began to discharge water that was heavily laden with sediment beginning in 2006 (fig. 13), and in 2007 a mudboil developed at the base of the well. Eventually, the fieldside well slowly tilted and eventually disappeared into the ground as subsidence continued in the area. During this time, all the turbid water and sediment were routed into the Rogue containment area. In March 2009, subsidence of the dike on the east (creek) side occurred as the creekside well also began to discharge sediment-laden water directly into Onondaga Creek; then a mudboil developed at the base of this well. A dike repair was made in spring 2009, and the flow from the creekside well was piped back into the Rogue area (fig. 4D). One year later the dike and well slowly subsided and eventually disappeared into the growing Rogue area subsidence. At this point there was no means to build a dike on the creek side of the Rogue area because the bed of the creek and the opposite, eastern streambank were also subsiding. Measures were proposed to route Onondaga Creek away from the Rogue area and to contain the Rogue discharge in order to retain the discharged sediment, but a lack of funds and an uncertain result led to inaction, allowing the Rogue area sediment to flow into Onondaga Creek. At that point, the water quality of the creek, in regard to the

\section{WY 2012}

Rogue area discharged on average about 20+ tons/day of sediment (suspended and bed load) to Onondaga Creek.

Rogue area continued to grow to the west (into the farm field) and to the south, eventually capturing the tributary channel from the MDA. This water now flows through the Rogue area and carries additional sediment to Onondaga Creek. Time lapse camera angle was changed and new subsidence in southwest Rogue area was captured by camera. Mudboil activity at the MDA was greatly reduced.

During 2012 all wells were closed (cemented-in) in the Onondaga and Tully Valleys. The last wells to be sealed were the flowing depressurizing wells (August 2012). A student working in the Rogue area documented the effect of closing the depressurizing wells as a perceived increased flow and measurable changes in water quality from Rogue mudboils (Sinclair, 2013).

Rattlesnake Gulf landslide area continued to grow, intermittently blocking Rattlesnake Gulf Creek and causing turbidity downstream. Rainbow Creek remained generally clear. All mudboil/Tully Valley area data collection activities ceased at the end of September 2012. 

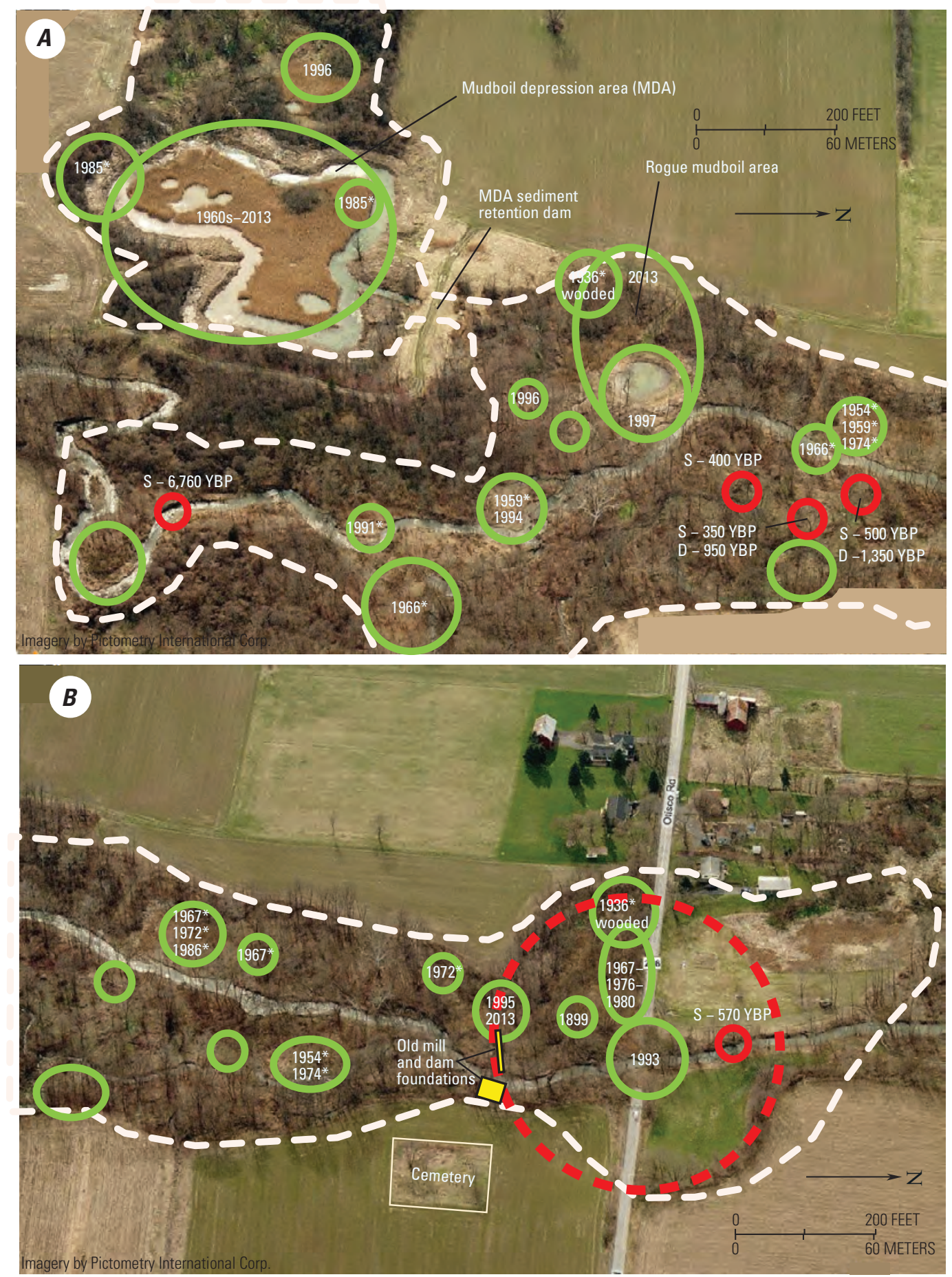

EXPLANATION

- Outline of Onondaga Creek mudboil corridor
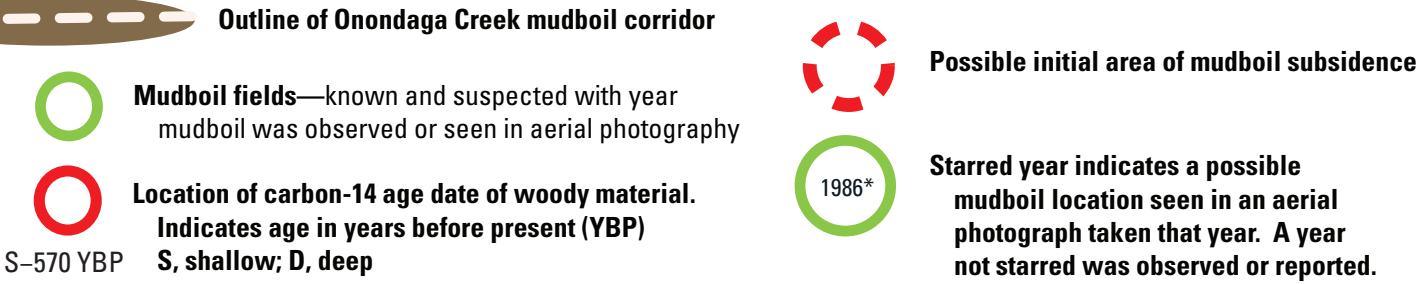

Starred year indicates a possible mudboil location seen in an aerial photograph taken that year. A year not starred was observed or reported.

Figure 12. The Onondaga Creek mudboil corridor in Tully Valley, Onondaga County, New York: $A$, southern end of mudboil corridor, and $B$, northern end, with the location of known and suspected mudboil areas within the corridor and the year in which they were observed in the field or in aerial photography, or the age determined from woody material using carbon-14 age-dating. 


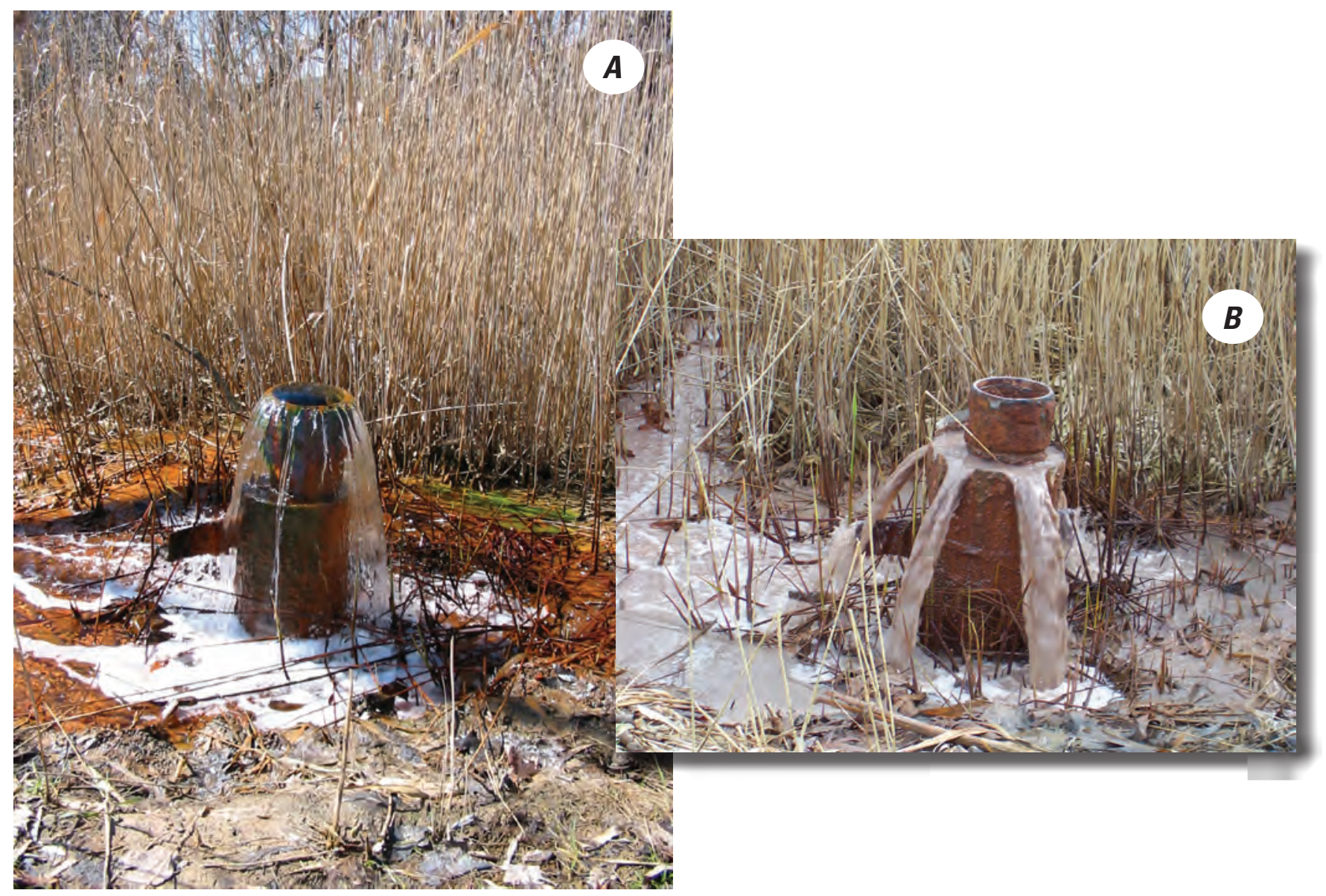

Figure 13. Mudboil depressurizing well OD 471, upgradient of the Rogue mudboil area, Tully Valley, Onondaga County, New York: $A$, in 2002, discharging clear but salty water at approximately 120 gallons per minute, and $B$, in 2006, after land-surface subsidence moved beyond this well, with surface casing discharging muddy and salty water at approximately 50 gallons per minute.

sediment loading, returned to what it was in the early 1990s; tens of tons per day of sediment were discharged directly into Onondaga Creek.

\section{Rogue Area Development-Likely Causes}

There are two likely and compounding reasons for the development of the Rogue area. First, the installation of the two depressurizing wells, finished in gravel with discharge rates much greater than any of the other depressurizing wells, might have allowed the area between the two wells to experience reduced artesian pressure, which, in turn, led to slow but continual land-surface subsidence, ring-fracture development, and lateral expansion of the Rogue mudboil area. Second, the effective capture of sediment in the nearby MDA over 12 years may have effectively capped off many of the discharging mudboils within the MDA, increasing artesian pressure in the mudboil aquifer(s). The nearby Rogue area provided a new route for this artesian pressure to be relieved, and the area grew as multiple mudboil vents, including the area around each of the lost depressurizing wells, allowed the Rogue area to become the primary location for mudboil discharge. Currently [2014], mudboil activity within the MDA is minor in comparison with what it was in the 1990s and early 2000s.
An analysis of several Rogue area mudboil vents during the summer of 2012 (Sinclair, 2013) indicated that in the Rogue area, the upper, fresher-water aquifer and the deeper brackishwater aquifer were discharging to particular mudboils, and their water quality (as measured by specific conductance) quickly worsened over a short period of time. This rapid change was attributed to diminished discharge from the upper mudboil aquifer, owing to reduced spring and summer recharge from the end moraine to the south and nearby side-valley alluvial fans at Rattlesnake Gulf and Rainbow Creeks. The closure of the remaining depressurizing wells in August 2012 caused an apparent increase in specific conductance from nearly all the Rogue area mudboils, and at the same time, there was the perception of increased flow from these mudboils. Discharge measurements for these mudboils could not be made, owing to the quicksand-like nature of sediments near active mudboil vents.

\section{Early Rogue-Like Subsidence Activity- A Retrospective Assessment}

In early aerial photography of the Rogue mudboil area (late 1930s), the eastern edge of the farm field, just south of the present Rogue mudboil area, was not a straight line as might be 
expected (fig. 14A). A semicircular area of subsidence appears to jut into the farm field, much as the current [2014] Rogue area does. It is likely that there was mudboil activity in this area a number of years before 1938, when the photograph was taken (possibly early 1900s), that likely caused mudboil development and related subsidence. Then, as mudboil activity moved elsewhere in the mudboil corridor, the subsided area slowly was revegetated. During the period of mudboil studies (1992-2012), the access road along the edge of the field dipped down into this depression and back out again; the significance of this depression in the access road was not appreciated until the Rogue area developed. The more recent photographs, (fig. 14B, $\mathrm{C}$, and D) show the progression of the new Rogue area between 2009 and 2012. The manner in which the subsidence moved into the farm field (fig. 14D) is likely the process by which the former subsidence area developed about 100 years previously.

\section{Stratigraphic Reversal and Mudboil Dynamics}

In summer 2010, two depressurizing wells were drilled southwest of the current [2014] Rogue mudboil area in an attempt to slow the migration of the Rogue area into the adjacent farm field. The two wells (OD 488 and OD 595) were drilled within the area of the suspected former Rogue subsidence area (1938); well OD 488 was drilled farther east and closer to the center of former Rogue area than OD 595. The $\log$ for OD 488 indicates the stratigraphy was almost entirely red clay, with very little sand encountered before the red till layer was reached at a depth of about 102 feet. Well OD 595, farther north and west of OD 488, penetrated more typical mudboil area stratigraphy, with about 42 feet of clay and silt, and with silty very fine sand laminations below. At a depth of about 94 feet, a layer of silty very fine to medium sand (about 9 feet thick) was penetrated just above the red till. At all other depressurizing- and monitoring-well locations drilled around the mudboil area, the confining clay and silt layer was 60 to 70 feet thick with a similar thickness of silty, very fine to medium sand above the red till.

The different stratigraphy penetrated by wells OD 488 and OD 595 demonstrates a general mudboil dynamic of (1) discharge (removal) from the lower silty very fine to medium sand (mudboil sediment); (2) subsidence of the overlying confining layer of clay and silt, which generally replaces the silty mudboil sediment removed at depth; and (3) eventual deposition of silty fine to medium sand at former land surface. This process, in effect, reverses the vertical sequence of the sediment stratigraphy at active and persistent mudboil discharge areas.

The amount of land-surface subsidence and resulting mudboil sediment deposition is likely determined by the persistence of mudboils in any particular area and by the amount of finer-grained sand and silt that is not removed by water flowing to a tributary stream or Onondaga Creek. The residual mudboil sediments left in place become the new land surface, which is generally vegetated by water-tolerant plant species because these sediments can be saturated by nearby mudboil activity.
This mudboil-development scenario described above has been suspected, but it was not validated until these two wells were drilled and their unique stratigraphy discerned as supporting this concept. The development of new mudboils in these areas is generally diminished because the aquifer material that supports such activity has been removed. Unless the lower mudboil aquifer can work its way through the red till layer, the mudboil activity will not be renewed. The telltale indication of this change would likely be a change in mudboil water quality - from fresh to brackish water discharge, as had been observed in the past and is occurring presently (2014) in the new Rogue area.

\section{Further Study and Possible Remediation Strategies for the Tully Valley}

As part of an Environmental Benefit Project overseen by the New York State Department of Environmental Conservation (NYSDEC), a local company has provided funds to the NYSDEC to determine what other strategies could be used to remediate the mudboils along Onondaga Creek. NYSDEC has proposed that, prior to any planning or implementation of new remedial projects, an expert panel be assembled and review data collected in the Tully Valley and then propose a combination of (1) further hydrogeologic study in areas of the valley that lack sufficient data to characterize the surface-water- and groundwater-flow systems that might be linked to the mudboils and other hydrogeologic phenomena in the valley, (2) possibly develop a groundwater-flow model to further characterize the hydraulic connections throughout the valley with the flow issuing from the mudboils, and (3) propose remedial strategies to reduce the effects of mudboil discharges and subsidence on the floor of the Tully Valley and the water quality of Onondaga Creek. Any remedial solutions determined under this program to control the mudboils and their effects over the long term would need to have limited operation and maintenance costs.

Past remedial activities at the mudboils were shown to be effective but had high maintenance costs and were ultimately overwhelmed by new mudboil activity elsewhere in the mudboil corridor. The movement of mudboils within the Onondaga Creek corridor cannot be projected, given the current [2014] understanding, nor are there enough data to design remedial measures elsewhere in the valley to control or reduce the artesian head that drives mudboil activity. The expert panel will need to discern how remedial projects might reduce the artesian head that drives mudboil activity, without eliminating all the artesian head, which supports the overlying glacial drift that composes the floor of the Tully Valley. Furthermore, the fresher water in the upper mudboil aquifer is apparently being replaced by more brackish water from the lower aquifer, and this poorer water quality will likely dominate the mudboil discharge in the future and may slowly affect the quality of water in Onondaga Creek. A careful balance among (1) reducing the head in the aquifer to slow mudboil activity, (2) reducing concurrent turbidity discharges to Onondaga Creek, and (3) minimizing land-surface subsidence associated with mudboil activity will need to be considered to maintain the chemical quality of Onondaga Creek. 


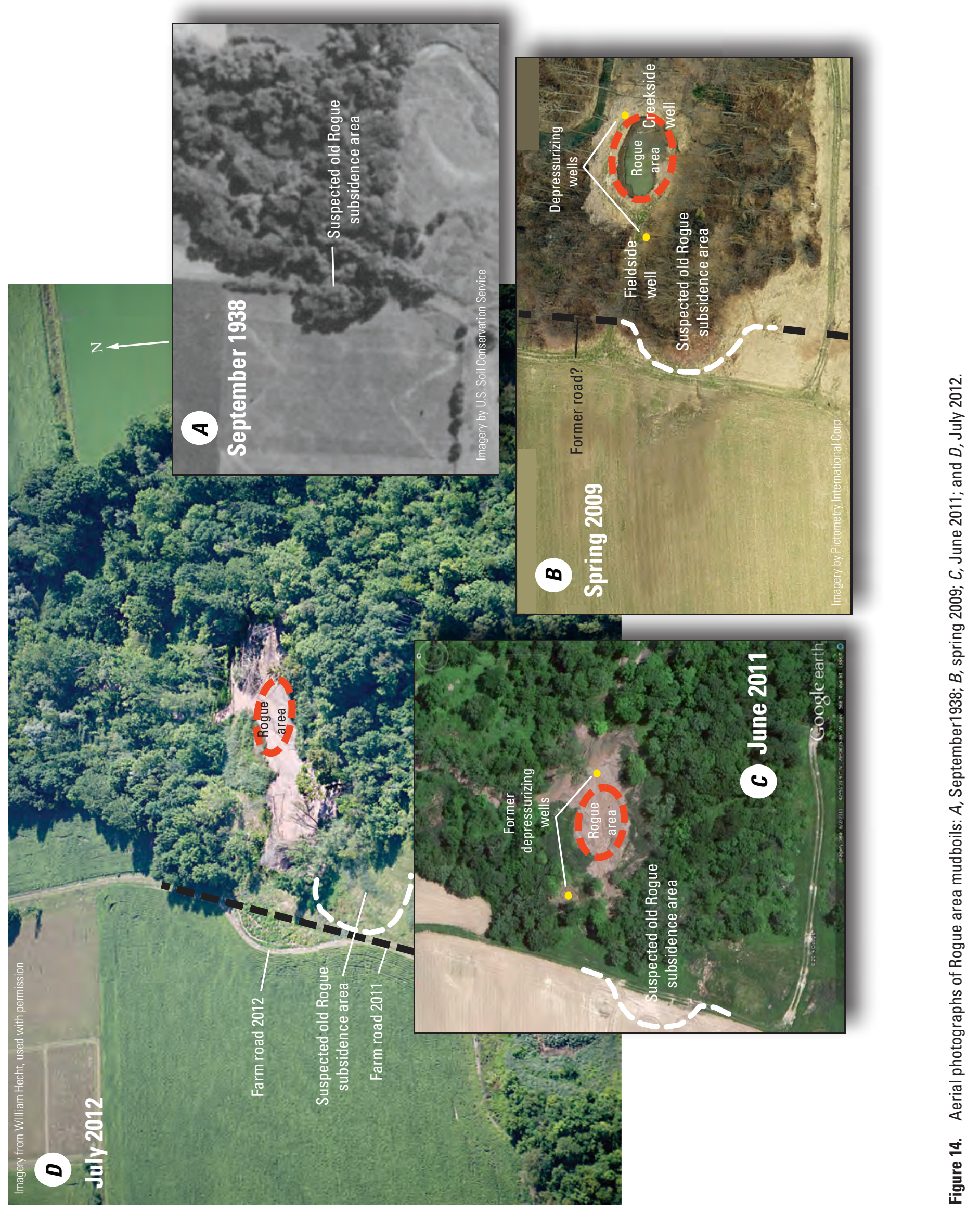




\section{Selected References}

Baldauf, Amanda, 2003, The origin of Onondaga valley brines-A geochemical investigation: Syracuse, N.Y., State University of New York master's thesis, $34 \mathrm{p}$.

Briggs, P.S., and Sanford, K.F., 2000, The ups and downs of post-closure subsidence monitoring at the Tully Valley brine field, New York: San Antonio, Tex., 15-18 October, 2000, Solution Mining Research Institute Technical Class Paper, $17 \mathrm{p}$.

Burgmeier, Phillip, 1998, A geotechnical investigation of the 1993 Tully Valley landslide: Syracuse, N.Y., Syracuse University master's thesis, $55 \mathrm{p}$.

Coon, W.F., 2008, Simulation of streamflow and selected waterquality constituents through a model of the Onondaga Lake basin, Onondaga County, NY-A guide to model application: U.S. Geological Survey Open-File Report 2008-1188, 27 p., http://pubs.usgs.gov/of/2008/1188/.

Coon, W.F., 2011, Improvement in precipitation-runoff model simulations by recalibration with basin-specific data, and subsequent model applications, Onondaga Lake Basin, Onondaga County, New York: U.S. Geological Survey Scientific Investigations Report 2011-5203, 37 p., http:/pubs.usgs.gov/sir/2011/5203/.

Coon, W.F., Hayhurst, B.A., Kappel, W.M., Eckhardt, D.A.V., and Szabo, C.O., 2009, Water-quality characterization of surface water in the Onondaga Lake basin, Onondaga County, New York, 2005-08: U.S. Geological Survey Scientific Investigations Report 2009-5246, 68 p., http://pubs.usgs.gov/ $\operatorname{sir} / 2009 / 5246 /$.

Coon, W.F., and Reddy, J.E., 2008, Hydrologic and waterquality characterization and modeling of the Onondaga Lake basin, Onondaga County, New York: U.S. Geological Survey Scientific Investigations Report 2008-5013, 88 p., http:// pubs.usgs.gov/sir/2008/5013/.

Curran, C.A., 1999, Saline springs of the 1993 Tully Valley landslide area - Evidence for brine migration and long term degradation of water quality in the Tully Valley, central New York: Syracuse, N.Y., Syracuse University master's thesis, $153 \mathrm{p}$.

Danehy, R.J., 1993, Evaluation of the aquatic environmental quality of Tully Valley: Syracuse, N.Y., State University of New York letter report, April 6, 1993, 8 p.

Epp, E.G., 2005, The sources and distribution of brines in sediment pore waters, Onondaga Valley, New York: Syracuse, N.Y., Syracuse University master's thesis, 111 p.

Fickies, R.H., 1993, A large landslide in Tully Valley, Onondaga County, New York: Association of Engineering Geologists News, v. 36, no. 4, p. 22-24.

Getchell, F.A., 1983, Subsidence in the Tully Valley, New York: Syracuse, N.Y., Syracuse University master's thesis, 108 p.
Hackett, W.R., 2007, An examination of the changing geologic conditions in a valley of former solution brine mining fields-Tully Valley, New York: Canton, N.Y., St. Lawrence University, bachelor's thesis, $58 \mathrm{p}$.

Hackett, W.R., Gleason, G.C., and Kappel, W.M., 2009, Landsurface subsidence and open bedrock fractures in the Tully Valley, Onondaga County, New York: U.S. Geological Survey Open-File Report 2009-1188, 16 p., http://pubs.usgs.gov/ of/2009/1188/.

Haley and Aldrich of New York, 1991, Report on mudboil occurrence in the Tully Valley, Onondaga County, New York: Rochester, N.Y., Allied Signal Inc., 18 p.

Hayhurst, Brett, and Kappel, W.M., 2013, Natural heat storage in a brine-filled solar pond in the Tully Valley of central New York: U.S. Geological Survey Open-File Report 2013-1266, 14 p., http://pubs.usgs.gov/of/2013/1266/pdf/ofr2013-1266. pdf.

Hornlein, J.F., Szabo, C.O., and Sherwood, D.A., 2004, Waterresources data-New York, water year 2003, volume 3, western New York: U.S. Geological Survey Water-Data Report NY-03-3, 354 p.

Hornlein, J.F., Szabo, C.O., and Sherwood, D.A., 2005, Waterresources data-New York, water year 2004, volume 3, western New York: U.S. Geological Survey Water-Data Report NY-04-3, 345 p.

Hornlein, J.F., Szabo, C.O., Sherwood, D.A., and McInnes, S.K., 2002, Water-resources data-New York, water year 2001, volume 3, western New York: U.S. Geological Survey Water-Data Report NY-01-3, 376 p.

Hornlein, J.F., Szabo, C.O., Sherwood, D.A., and McInnes, S.K., 2003, Water-resources data-New York, water year 2002, volume 3, western New York: U.S. Geological Survey Water-Data Report NY-02-3, 314 p.

Hornlein, J.F., Szabo, C.O., and Zajd, H.J., Jr., 1995, Waterresources data-New York, water year 1994, volume 3, western New York: U.S. Geological Survey Water-Data Report NY-94-3, 341 p.

Hornlein, J.F., Szabo, C.O., Zajd, H.J., Jr., and Deloff, D.D., 1993, Water-resources data-New York, water year 1992, volume 3, western New York: U.S. Geological Survey WaterData Report NY-92-3, 303 p.

Hornlein, J.F., Szabo, C.O., Zajd, H.J., Jr., and Deloff, D.D., 1994, Water-resources data-New York, water year 1993, volume 3, western New York: U.S. Geological Survey WaterData Report NY-93-3, 289 p.

Hornlein, J.F., Szabo, C.O., Zajd, H.J., Jr., and Mulks, R.L., 1996, Water-resources data-New York, water year 1995, volume 3, western New York: U.S. Geological Survey WaterData Report NY-95-3, 339 p.

Hornlein, J.F., Szabo, C.O., Zajd, H.J., Jr., and Mulks, R.L., 1997, Water-resources data-New York, water year 1996, volume 3, western New York: U.S. Geological Survey WaterData Report NY-96-3, 300 p. 
Hornlein, J.F., Szabo, C.O., Zajd, H.J., Jr., and Mulks, R.L., 1998, Water-resources data-New York, water year 1997, volume 3, western New York: U.S. Geological Survey WaterData Report NY-97-3, 346 p.

Hornlein, J.F., Szabo, C.O., Zajd, H.J., Jr., and Mulks, R.L., 1999, Water-resources data-New York, water year 1998, volume 3, western New York: U.S. Geological Survey WaterData Report NY-98-3, 383 p.

Hornlein, J.F., Szabo, C.O., Zajd, H.J., Jr., and Mulks, R.L., 2000, Water-resources data-New York, water year 1999, volume 3, western New York: U.S. Geological Survey WaterData Report NY-99-3, 372 p.

Hornlein, J.F., Szabo, C.O., Zajd, H.J., Jr., and Mulks, R.L., 2001, Water-resources data-New York, water year 2000, volume 3, western New York: U.S. Geological Survey WaterData Report NY-00-3, 404 p.

Jäger, Stephan, and Wieczorek, G.F., 1994, Landslide susceptibility in the Tully Valley area, Finger Lakes Region, New York: U.S. Geological Survey Open-File Report 94-0615, 1 plate.

Kappel, W.M., 2000, Salt production in Syracuse, New York ("the salt city") and the hydrogeology of the Onondaga Creek Valley: U.S. Geological Survey Fact Sheet 2000-139, 8 p., http://ny.water.usgs.gov/pubs/fs/fs13900/.

Kappel, W.M., 2009, Remediation of mudboil discharges in the Tully Valley of Central New York: U.S. Geological Survey Open File Report 2009-1173, 8p., http://pubs.usgs.gov/ of/2009/1173/.

Kappel, W.M., and McPherson, W.S., 1998, Remediation of mudboil discharges in the Tully Valley of Central New York: U.S. Geological Survey Fact Sheet 97-143, 4 p., http:// ny.water.usgs.gov/pubs/fs/fs14397/.

Kappel, W.M., and Miller, T.S., 2003, Hydrogeology of the Tully trough - Southern Onondaga County and northern Cortland County, New York: U.S. Geological Survey WaterResources Investigations Report 03-4112, 16 p., http:// ny.water.usgs.gov/pubs/wri/wri034112/.

Kappel, W.M., and Miller, T.S., 2005, Hydrogeology of the valley-fill aquifer in the Onondaga Trough, Onondaga County, New York: U.S. Geological Survey Scientific Investigations Report 2005-5007, 13 p., http://ny.water.usgs. gov/pubs/wri/sir055007/.

Kappel, W.M., Miller, T.S., and Hetcher, K.K., 2001, Hydrogeology of the Tully Lakes area in southern Onondaga and northern Cortland Counties, New York: U.S. Geological Survey Water-Resources Investigations Report 01-4166, 16 p., http://ny.water.usgs.gov/pubs/wri/wri014166/.
Kappel, W.M., Sherwood, D.A., and Johnston, W.H., 1996, Hydrogeology of the Tully Valley and characterization of mudboil activity, Onondaga County, New York: U.S. Geological Survey Water-Resources Investigations Report 96-4043, 71 p., http://ny.water.usgs.gov/pubs/wri/ wri964043/.

Kappel, W.M., and Teece, M.A., 2007, Paleoenvironmental assessment and deglacial chronology of the Onondaga Trough, Onondaga County, New York: U.S. Geological Survey Open-File Report 2007-1060, 12 p., http://pubs.usgs. gov/of/2007/1060/.

Kappel, W.M., and Yager, R.M., 2008, Ground-water-flow modeling of a freshwater and brine-filled aquifer in the Onondaga Trough, Onondaga County, New York-A summary of findings: U.S. Geological Survey Open-File Report 2007-1409, 12 p., http://pubs.usgs.gov/of/2007/1409.

McKenna, J.E., Chiotti, T.L., and Kappel, W.M., 1999, Ecological status of Onondaga Creek in Tully Valley, New York-Summer 1998: U.S. Geological Survey Fact Sheet FS 141-99, 6 p., http://ny.water.usgs.gov/pubs/fs/fs14199/.

Morales-Muniz, P.J., 2000, The Tully Valley flowslide of 1993, Lafayette, New York: West Lafayette, Ind., Purdue University master's thesis, $176 \mathrm{p}$.

Mullins, H.T., Hinchey, E.J., Wellner, R.W., Stephens, D. B., Anderson, W.T., Jr, Dwyer, T.R., and Hine, A.C., 1996, Seismic stratigraphy of the Finger Lakes - A continental record of Heinrich event $\mathrm{H}-1$ and Laurentide ice sheet instability, in Mullins, H.T., and Eyles, Nicholas, eds., Subsurface geologic investigations of New York Finger Lakes-Implications for Late Quaternary deglaciation and environmental change: Boulder, Colo., Geological Society of America Special Paper 311, 35 p.

New York State Department of Environmental Conservation, [2014], History of state forest program: Department of Environmental Conservation Web page, accessed May 14, 2014, at http:/www.dec.ny.gov/lands/4982.html.

Pair, D.L., Kappel, W.M., and Walker, M.S., 2000, History of landslides at the base of Bare Mountain, Tully Valley, Onondaga County, New York: U.S. Geological Survey Fact Sheet FS 0190-99, 6 p., http://ny.water.usgs.gov/pubs/fs/ fs $19099 /$.

Rubin, P.A., Ayers, J.C., and Grady, K.A., 1991, Solution mining and resultant evaporate karst development in Tully Valley, New York, in, Quinland, J.F., and Stanley, Anita, eds., Hydrology, ecology, monitoring, and management of ground water in karst terranes-Proceedings of the $3 \mathrm{~d}$ annual conference, Dublin, Ohio, National Ground Water Association, p. 313-328.

Simpson, K.W., 1982, Technical Memorandum-Biological Survey of Onondaga Creek: Albany, N.Y., State of New York Department of Health, Environmental Health Laboratory Institute, $28 \mathrm{p}$. 
Sinclair, G.J., 2013, Going rogue-Dynamics of the Tully Valley mudboils 1936-2012: Cambridge, United Kingdom, University of Cambridge undergraduate dissertation, $84 \mathrm{p}$.

Snell, Laura, 1992, Comments on mudboil working group management plan: Albany, N.Y., New York State Department of Environmental Conservation, Division of Mineral Resources letter, February 19, 1992, 12 p.

Solvay Process Company, The, 1950, Tully brine well data and brief history-Memorandum (La-3-R): Syracuse, N.Y., Solvay Process Division, Allied Chemical and Dye Corporation, $25 \mathrm{p}$.

Solvay Process Company, The, 1960, Investigation-Tully brine field-A history of development-Memorandum (8JEM-119): Syracuse, N.Y., Solvay Process Division, Allied Chemical and Dye Corporation, $17 \mathrm{p}$.

Tamulonis, K.L., 2010, Current geologic issues in New York State-From carbon dioxide storage to landsliding: Ithaca, N.Y., Cornell University doctoral dissertation, 245 p.

Tamulonis, K.L., and Kappel, W.M., 2009, Dendrogeomorphic assessment of the Rattlesnake Gulf landslide in the Tully Valley, Onondaga County, New York: U.S. Geological Survey Scientific Investigations Report 2009-5134, 14 p., http:// pubs.usgs.gov/sir/2009/5134/.

Tamulonis, K.L., Kappel, W.M., and Shaw, S.B., 2009, Causes and movement of landslides at Rainbow Creek and Rattlesnake Gulf in the Tully Valley, Onondaga County, New York: U.S. Geological Survey Scientific Investigations Report 2009-5114, 18 p., http://pubs.usgs.gov/sir/2009/5114/.

U.S. Geological Survey, 2013a, Annual water-data reports (2005-2012): U.S. Geological Survey New York Water Science Center Web page, accessed September 2013 at http:// ny.water.usgs.gov/htmls/pub/data.html.
U.S. Geological Survey, 2013b, USGS water data for New York: U.S. Geological Survey National Water Information System, accessed September 2013 at http://waterdata.usgs. gov/ny/nwis/nwis.

Waller, R.M., 1977, Subsidence in New York related to groundwater discharge: U.S. Geological Survey Professional Paper $1050,258 \mathrm{p}$.

West, C.V., 1981, 1700 Milton Avenue-The Solvay story, 1881-1981: Solvay, N.Y., Allied Chemical Corporation, 44 p.

Wieczorek, G.F., Negussey, Dawit, and Kappel, W.M., 1998, Landslide hazards in glacial lake clays - Tully Valley, New York: U.S. Geological Survey Fact Sheet 98-013, 4 p., http:// pubs.er.usgs.gov/pubs/fs/fs01398.

Wurst, Louann, 1994, Stage 1A cultural resource survey-Tully Valley mudboils corridor-Town of Lafayette, Onondaga County, New York: Binghamton, N.Y., Public Archaeology Facility at Binghamton University, 41 p.

Yager, R.M., Kappel, W.M., and Plummer, L.N., 2007a, Origin of halite brine in the Onondaga Trough near Syracuse, New York State, USA - Modeling geochemistry and variabledensity flow: Hydrogeology Journal, p. 1321-1339, http:// www.springerlink.com/content/008m772313n73413/.

Yager, R.M., Kappel, W.M., and Plummer, L.N., 2007b, Halite brine in the Onondaga Trough near Syracuse NYCharacterization and simulation of variable-density flow: U.S. Geological Survey Scientific Investigations Report 2007-5058, 40 p., http://pubs.usgs.gov/sir/2007/5058.

Yanosky, T.M., and Kappel, W.M., 1998, Tree rings record 100 years of hydrologic change within a wetland: U.S. Geological Survey Fact Sheet FS 0057-97, 4 p., http://ny.water.usgs.gov/ pubs/fs/fs05797/.

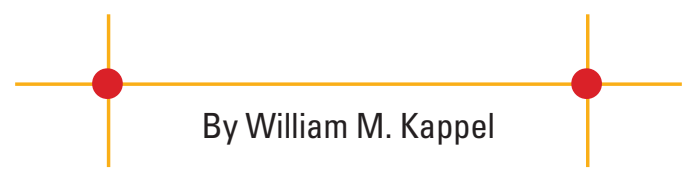




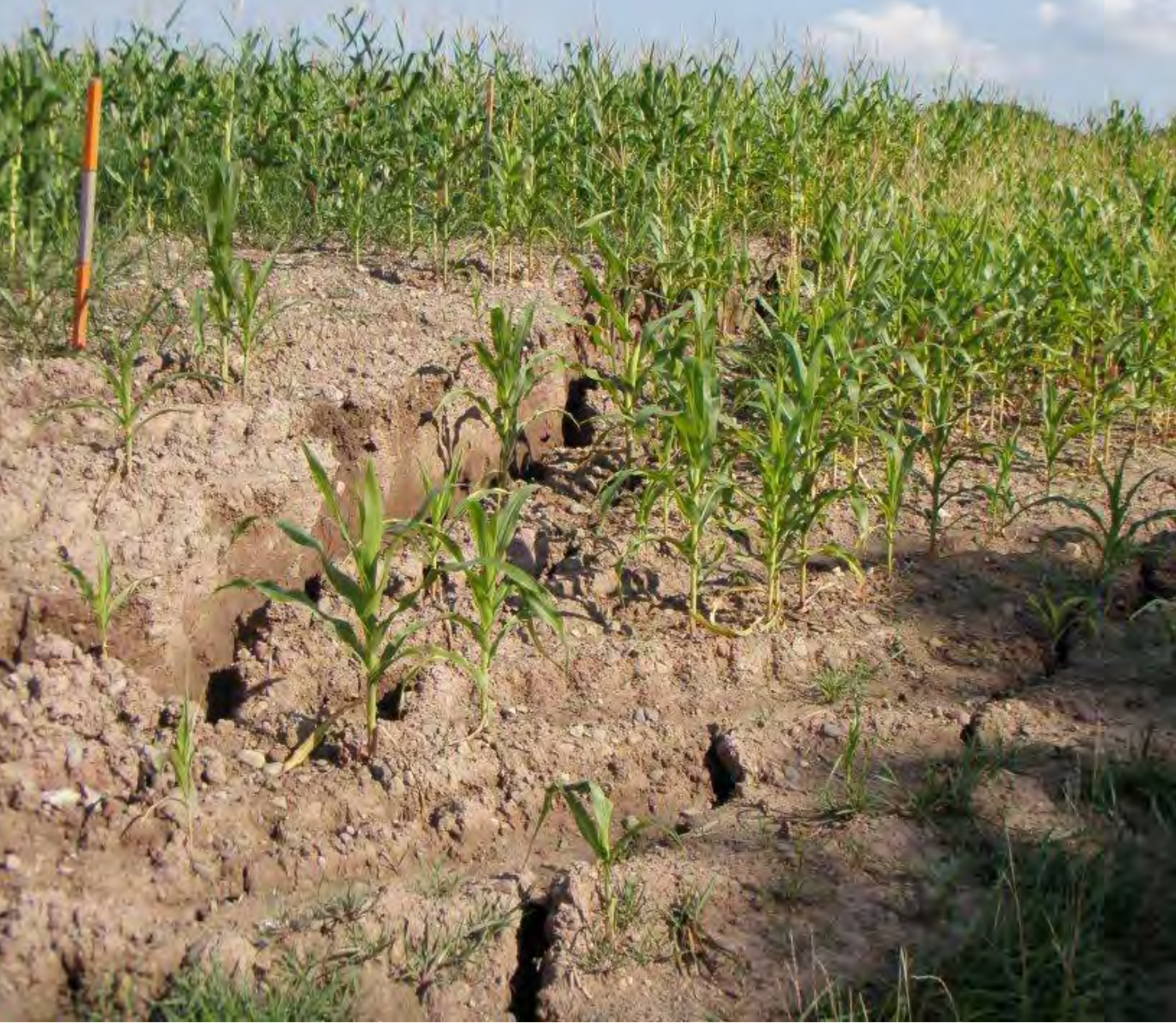

Subsidence scarps on west side of Rogue mudboil area, August 2011. Note the corn, planted several months before this subsidence occurred, is now on the lower scarps.

\section{For additional information write to:}

New York Water Science Center

U.S. Geological Survey

30 Brown Road

Ithaca, NY 14850
For more information on the USGS - the Federal source for science about the Earth, its natural and living resources, natural hazards, and the environment, visit http://www.usgs.gov or call 1-888-ASK-USGS.
Any use of trade, firm, or product names is for descriptive purposes only and does not imply endorsement by the U.S. Government. 